\title{
What can primary care services do to help First Nations people with unhealthy alcohol use? A systematic review: Australia, New Zealand, USA and Canada
}

Gemma C. Purcell-Khodr ${ }^{*} \mathbb{D}$, K. S. Kylie Lee ${ }^{1,2}$, James H. Conigrave ${ }^{1}$, Emma Webster ${ }^{3}$ and Katherine M. Conigrave $e^{1,4}$

\begin{abstract}
Background: First Nations peoples of Australia, New Zealand, the United States of America (USA) and Canada are more likely to be non-drinkers than other people in these countries. However, those who do drink may be at greater risk of alcohol-related harms (at a population level) due to the ongoing impacts from colonisation and associated oppression. Addressing unhealthy drinking (drinking above recommended limits including alcohol use disorders) in primary care settings is one important way to increase accessibility of treatment.

Methods: This systematic review identifies peer-reviewed studies of alcohol treatments delivered in primary care or other non-residential settings for First Nations peoples of Australia, New Zealand, USA and Canada. Literature searches were conducted in seven academic databases from their inception until March, 2020. We assessed evidence of treatment or implementation effectiveness, perceived acceptability or accessibility, and the study quality as assessed by the AXIS tool and by a measure of community participation in the research process.

Results: Twenty-eight studies were included, published between 1968 and 2018. Studies reported on a range of alcohol treatments, from brief intervention to ambulatory withdrawal management, relapse prevention medicines, and cultural therapies. Brief intervention was the most studied approach. Cultural healing practices and bicultural approaches were a key theme amongst several studies. Four studies measured treatment effectiveness, including one randomised controlled trial (naltrexone vs naltrexone plus sertraline vs placebo) and two uncontrolled trials of disulfiram. Of the six implementation studies, three were (hybrid) effectiveness-implementation designs. Most of the remaining studies $(n=21)$ focused on treatment accessibility or acceptability. Community participation in the research process was poorly reported in most studies.

Conclusions: Research evidence on how best to care for First Nations peoples with unhealthy alcohol use is limited. Trials of naltrexone and disulfiram presented promising results. Cultural and bicultural care were perceived as highly important to clinical staff and clients in several studies. More effectiveness studies on the full scope of alcohol treatments are needed. Greater community participation in research and more transparent reporting of this in study methods will be key to producing quality research that combines scientific rigour with cultural appropriateness.
\end{abstract}

\footnotetext{
*Correspondence: gemma.khodr@sydney.edu.au

${ }^{1}$ Faculty of Medicine and Health, Sydney School of Medicine; NHMRC

Centre of Research Excellence in Indigenous Health and Alcohol,

University of Sydney, Camperdown, NSW, Australia

Full list of author information is available at the end of the article
}

(c) The Author(s) 2020. This article is licensed under a Creative Commons Attribution 4.0 International License, which permits use, sharing, adaptation, distribution and reproduction in any medium or format, as long as you give appropriate credit to the original author(s) and the source, provide a link to the Creative Commons licence, and indicate if changes were made. The images or other third party material in this article are included in the article's Creative Commons licence, unless indicated otherwise in a credit line to the material. If material is not included in the article's Creative Commons licence and your intended use is not permitted by statutory regulation or exceeds the permitted use, you will need to obtain permission directly from the copyright holder. To view a copy of this licence, visit http://creativeco mmons.org/licenses/by/4.0/. The Creative Commons Public Domain Dedication waiver (http://creativecommons.org/publicdomain/ zero/1.0/) applies to the data made available in this article, unless otherwise stated in a credit line to the data. 
Keywords: Indigenous, First Nations, Alcohol, Primary health care, Outpatient, Relapse prevention medicines, Naltrexone, Disulfiram, Culture, Cultural healing

\section{Background}

Globally, unhealthy alcohol use is a leading cause of mortality and disability [1]. Unhealthy use includes the full spectrum of drinking above recommended limits, from hazardous alcohol use to severe alcohol use disorders. Harms from alcohol are exacerbated by colonial legacies which see First Nations peoples bearing a disproportionate burden of disease [1]. In this review, the term 'First Nations' will be used to respectfully refer to the distinct and diverse Indigenous tribal groups of all included countries, including Inuit and Métis peoples of Canada.

Alcohol consumption patterns in First Nations people of Australia, New Zealand, the United States of America (USA) and Canada have some similarities. Amongst these populations, data suggests a polarising trend to either abstinence or episodic heavy drinking [2-4]. For example, in Australia, Aboriginal and Torres Strait Islander peoples are more likely to abstain from drinking than their non-Indigenous counterparts [2]. However, as a population they are estimated to be $20-30 \%$ more likely to drink above recommended levels, and experience at least twice as many alcohol-related hospitalisations $[5,6]$. These patterns do not represent individual vulnerability. There is large variability within and between communities [7, 8]. Complex sociocultural factors resulting from colonisation have exposed First Nations peoples to additional risks of harms from alcohol [9]. Factors include cultural hegemony (where the colonising culture dominates), racism, transgenerational trauma, unemployment, poor housing and disconnection from ancestral homelands, family and culture [9-11].

Primary care services can play an important role in helping people to change their alcohol consumption $[12,13]$. In this systematic review, primary care is defined as the first point of contact with the health care system where generalist, holistic care is delivered, minimising the need for specialist care where safe to do so $[14,15]$. There are a wide range of treatments available for unhealthy alcohol use in primary health settings $[16,17]$. Brief interventions (BI) can be provided to individuals with hazardous or harmful drinking (non-dependent, or mild alcohol use disorders [AUDs]) [16]. For those with alcohol dependence (moderatesevere AUDs), motivational interviewing and other psychosocial therapies are available, though research on their effectiveness in primary care settings is limited
$[18,19]$. Where alcohol withdrawal management is necessary, home detoxification (ambulatory management) can be provided for carefully selected individuals [20, 21]. Pharmacotherapies such as naltrexone and acamprosate have been found to prevent relapse in combination with ongoing psychosocial supports and counselling amongst the general population in primary care settings [22]. These treatments offer promise for First Nations peoples, although minimal research has been done in this area [23, 24]. Those with severe alcohol dependence, or significant physical or mental health disorders or major social challenges, often require referral to a specialist service, and sometimes inpatient or residential care $[16,25]$.

For First Nations Peoples, the ability to receive treatment in primary health settings may be important due to several factors. For example, access to treatment 'on Country' (traditional homelands) or within one's community is linked with spiritual, emotional and physical well-being [26-28]. Furthermore, kinship obligations (cultural caring) to children, partners and large extended families are a deterrent for individuals to travel for treatment, which for alcohol dependence may be for extended periods due to the relapsing nature of the condition. There are also financial barriers, including cost of transport, which may make residential facilities hard to access [29-31]. First Nations peoples may also fear discrimination in mainstream residential services [29, 32]. In addition, there is less stigma attached to attending primary care than to a specialised drug and alcohol unit [29]. From a health policy perspective, delivering alcohol care locally where it is appropriate, is also an economical and pragmatic solution to the chronic shortage of places in hospitals and residential rehabilitation services [33, 34].

Research on alcohol care in primary services for First Nations peoples has followed a similar trajectory as research on interventions for the general population. Historically abstinence-oriented approaches for treatment of alcohol dependence dominated [35]. From the 1980 s a broader treatment philosophy arose, including earlier intervention and harm-reduction for those who cannot or do not want to change their drinking [35-37]. A greater understanding of the social determinants of health and the importance of 'cultural competency' or 'cultural safety' for First Nations peoples also has been embraced [38-40]. These two terms refer to ethical and effective conduct in cross-cultural settings, where the clinician's own cultural values and 
worldview are acknowledged and implications of these (for interactions) are considered [41].

A recurring challenge in health research for First Nations peoples has been the epistemology underpinning research methods. In many cases the scientific approach has been at odds with Indigenous 'ways of knowing' $[42,43]$. There is growing recognition of the need for culturally-informed studies, and for research methodology that has a decolonising frame [44, 45]. Involving First Nations communities in the co-design and co-production of research that impacts them is encouraged to meet ethical obligations and produce quality research [46].

There is a need to consolidate knowledge on the range of alcohol treatments available for First Nations clients in a primary care setting. In this paper we present a systematic review of the current evidence on treatments for unhealthy alcohol use in such settings. The aims were to: (1) quantify the number of peer-reviewed publications; (2) document the treatment approaches which have been studied (western or cultural) and assess evidence of their effectiveness; and (3) comment on the quality of the studies; both in terms of appraisal of study quality using a published scientific appraisal tool, and from assessing extent of community participation in the research process.

\section{Methods}

A systematic search of peer-reviewed literature was conducted to determine what treatments are readily accessible in primary care to help First Nations individuals with unhealthy drinking.

The following electronic databases were searched on March 11, 2020: CINAHL, Psychinfo, Scopus, Informit, Medline, Web of Science and PubMed. Three other databases were also searched: Google Scholar, Australian Indigenous HealthInfoNet (including the Alcohol and Other Drugs Knowledge Centre) and the Lowitja Institute. Search terms are listed in Table 1, and included terms for population, country, substance, treatment and setting. Syntax and subject headings were adapted for each database as necessary. In one instance a set of search filters was applied to optimise search results in the PubMed database. These search filters are available at the Lowitja Institute [47] and were developed to link all variants of the term 'Aboriginal' with major topics in Indigenous (Australian) health. Additional records were identified by handsearching reference lists and consulting researchers from the field.

\section{Inclusion criteria}

Studies were included if: (1) they presented data on programs or interventions for reducing alcohol consumption or the harms caused by unhealthy alcohol use in First Nations individuals from Australia, New Zealand, United States of America, or Canada; (2) the program

Table 1 Search strategy

\begin{tabular}{|c|c|c|c|c|c|c|c|c|}
\hline Population & & & Country & & Treatment & & Setting & \\
\hline $\begin{array}{l}\text { Indigenous } \\
\text { Aboriginal } \\
\text { "First Nation*" } \\
\text { "First people*" } \\
\text { "Torres Strait } \\
\text { Island*" } \\
\text { Maori* } \\
\text { Native* } \\
\text { "Native Ameri- } \\
\text { can" } \\
\text { "American } \\
\text { Indian*" } \\
\text { Indian* } \\
\text { Inuit* } \\
\text { Metis } \\
\text { Alaska* }\end{array}$ & $\begin{array}{l}\text { Aleut* } \\
\text { Inupiat* } \\
\text { Yuit } \\
\text { Athabascan* } \\
\text { Tlingit* } \\
\text { Haida* } \\
\text { Navajo* } \\
\text { Cherokee* } \\
\text { Arikara* } \\
\text { Iroquois* } \\
\text { Pawnee* } \\
\text { Sioux* } \\
\text { Apache* } \\
\text { Comanche* } \\
\text { Cree }^{*} \\
\text { Ojibwa* } \\
\text { Mohawk* } \\
\text { Duwamish }\end{array}$ & $\begin{array}{l}\text { Cheyanne* } \\
\text { Blackfoot } \\
\text { Seminole* } \\
\text { Hopi Sho- } \\
\text { shone* } \\
\text { Mohican* } \\
\text { Shawnee* } \\
\text { Mi'kmaq* } \\
\text { Crow* } \\
\text { Paiute } \\
\text { Wampanoag* } \\
\text { Ho-chunk* } \\
\text { Chumash* } \\
\text { Haida* } \\
\text { Suquamish } \\
\text { "Oceanic } \\
\text { ancestry } \\
\text { group" }\end{array}$ & $\begin{array}{l}\text { Austral* } \\
\text { Canad* } \\
\text { North } \\
\text { Americ* } \\
\text { USA } \\
\text { "United } \\
\text { States of } \\
\text { America" } \\
\text { Americ* } \\
\text { Alaska* } \\
\text { New } \\
\text { Zealand* } \\
\text { Hawaii* }\end{array}$ & Alcohol* & $\begin{array}{l}\text { Naltrexone } \\
\text { Acamprosate } \\
\text { Disulfiram } \\
\text { Counsel* } \\
\text { Men* group* }^{*} \\
\text { Women* group* } \\
\text { Culture } \\
\text { Cultural approach* } \\
\text { Cultural healing } \\
\text { Traditional culture* } \\
\text { Home detox* } \\
\text { Healing circle* }\end{array}$ & $\begin{array}{l}\text { Intervention* } \\
\text { Program* } \\
\text { Sweat lodge* } \\
\text { Brief interven- } \\
\text { tion* } \\
\text { CBT } \\
\text { DBT } \\
\text { Cognitive } \\
\text { behavioural } \\
\text { therap* } \\
\text { Cognitive } \\
\text { behavioral } \\
\text { therap* } \\
\text { Dialectic } \\
\text { behavioural } \\
\text { therap* } \\
\text { Dialectic } \\
\text { behavioral } \\
\text { therap* } \\
\text { Relapse } \\
\text { prevention } \\
\text { medicine* } \\
\text { Motivational } \\
\text { Interview }\end{array}$ & $\begin{array}{l}\text { Outpatient } \\
\text { Primary care } \\
\text { Primary health } \\
\text { care } \\
\text { General prac- } \\
\text { tice* } \\
\text { GP* }^{*} \\
\text { Doctor* } \\
\text { Physician* } \\
\text { Family practic* } \\
\text { Medical } \\
\text { practic* } \\
\text { Medical } \\
\text { center* } \\
\text { Medical } \\
\text { centre* }\end{array}$ & $\begin{array}{l}\text { Aboriginal medical } \\
\text { service } \\
\text { Aboriginal health } \\
\text { service } \\
\text { "Aboriginal Com- } \\
\text { munity Controlled } \\
\text { Health Service" } \\
\end{array}$ \\
\hline
\end{tabular}


or intervention was aimed at individuals with known unhealthy drinking (i.e. above recommended limits 'hazardous drinking' or an alcohol use disorder), OR aimed at improving accessibility or acceptability of alcohol care in primary health care services; (3) the program or interventions were implemented in a primary care setting or other setting that was readily available to individuals in the community on an outpatient basis and; (4) data on First Nations participants was presented separately to other ethnic groups. Studies focusing on Alcoholics Anonymous' or similar mutual support groups were excluded as they are the subject of a separate review [48]. Studies which focused solely on screening were excluded. No language restrictions were implemented. Due to the dearth of research on this topic, no start date for the search was specified. Databases were searched from inception to 11 March 2020.

\section{Record screening}

The search strategy was developed (GK, KC, KL) and then refined by two academic librarians. The search was conducted by one author (GK) and titles and abstracts of all retrieved articles were screened and reviewed independently by two authors (GK and KL). Discrepancies were discussed and resolved by consensus. Papers meeting inclusion criteria were subject to a full-text screen conducted independently by three authors (GK, KL, JC). Disagreements were debated and where unable to be resolved, an additional author adjudicated (KC). Reference lists of included articles from the full-text screen and articles recommended by colleagues were reviewed (GK) against the inclusion criteria. These additional papers were independently full-text screened (by GK and either KL or JC). No disagreements were found. A summary of the articles retrieved is presented in Fig. 1.

\section{Data extraction}

Data extraction was completed by GK. Two authors ( $\mathrm{KL}$ and $\mathrm{JC})$ independently extracted data from half of the articles each. Care was taken to not allocate these authors any article on which they were a co-author. Data extracted included country and Indigenous population, participant characteristics, data collection methods, nature of the conditions treated, system used to categorise participants' alcohol use, treatment strategy type (western [i.e. mainstream or non-Indigenous] or cultural), study focus (e.g. treatment effectiveness, implementation), length of follow-up, intervention details and outcomes. Studies that focused on implementation research were categorised according to a framework developed for the WHO [49], as either implementation or effectiveness-implementation design. The latter examines both the treatment effectiveness and implementation processes. 'Western' studies were defined as those that did not explicitly mention Indigenous cultural values or practices. 'Cultural' studies were grounded in traditional practices and philosophies of the respective First Nations participants. The three authors resolved discrepancies to form a combined version of data. Data extraction was independently checked (KC).

\section{Quality assessment}

Study quality and risk of bias assessment was conducted using two tools: a version of the AXIS critical appraisal tool [50], which was later adapted by its authors to include assessment of the quality of randomised controlled trial (RCT) and cohort designs; and an adapted version of a tool to assess community participation in research [51-53]. The latter categorises First Nations community participation across seven levels, from no participation to self-mobilisation. Studies are classified on this scale based on participation at four time-points during research projects: diagnosis (identifying a community's priorities), development (appropriate strategies to address the priorities), implementation (of the strategies) and evaluation (of the effectiveness of the project; Table 2). Scoring was conducted independently by three authors (GK, KL, JC). Discrepancies were discussed and resolved by consensus. Where participation data was not presented or unclear, an 'unknown' classification was allocated.

\section{Results}

Twenty-eight records met the selection criteria (Fig. 1). The included articles were published between 1968 and 2018, with the majority after $2010(n=19)$ [29-31, 5469]. Most studies were conducted in Australia $(\mathrm{n}=17)$ $[29,30,54-62,65,67,68,70-72]$, followed by the USA $(\mathrm{n}=7)[24,31,66,69,73-75]$, Canada $(\mathrm{n}=2)[63,64]$ and New Zealand $(\mathrm{n}=2)[76,77]$ (Table 3).

\section{Study characteristics}

Studies examined treatments for a range of severity of unhealthy alcohol use, from hazardous use to alcohol dependence. Nine studies focussed on alcohol dependence or 'alcoholism' (sic) [24, 29, 56, 64, 69, 72-75]. Two studies focused on alcohol use disorders more broadly (severity not specified) [30, 31]. No study was found to exclude clients with dependence. Of the remaining 17 studies, a variety of terms were used to describe the nature of the alcohol problem being treated (Table 3). No diagnostic criteria or screening thresholds were provided for the majority $(n=19,68 \%)$ of studies (Table 4$)$. Of the 28 studies, almost half $(\mathrm{n}=13 ; 46.5 \%)$ were quantitative $[24,55,57,61,62,69,70,72-77]$, nine were qualitative 


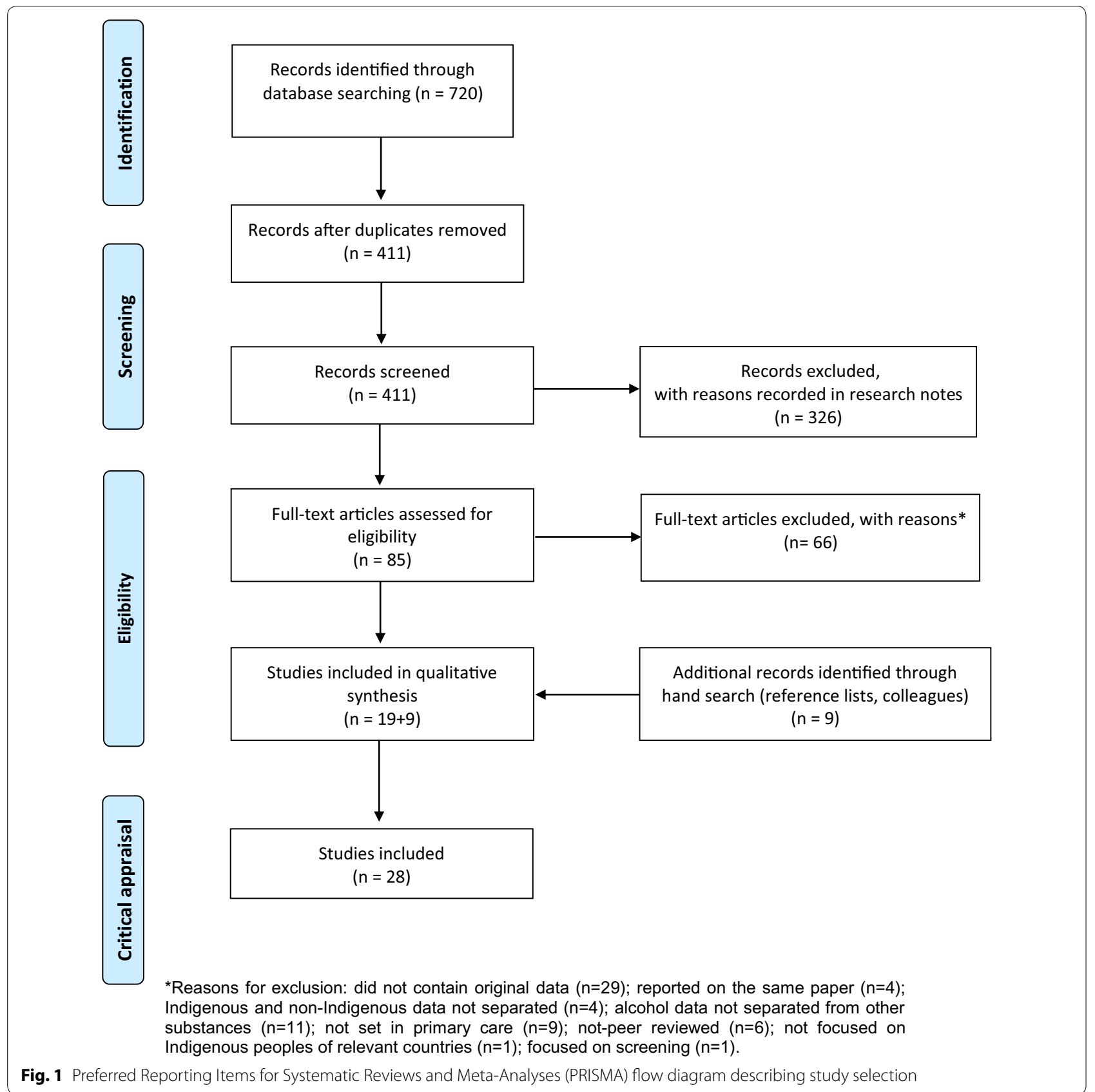

(32\%) $[31,54,56,58,60,63,64,66,71]$, and six were mixed methods (21.5\%) [29, 30, 59, 65, 67, 68].

Study interventions, primary outcomes, and analytic strategies were highly varied. We classified studies according to their research focus (Table 3). Two-thirds $(n=18)$ of the studies focused on treatment accessibility or acceptability from the perspective of clients $(n=6)$, staff $(\mathrm{n}=8)$ or both $(\mathrm{n}=4)[30,31,55,57,65,76]$; [54, $56,58,60,68,70,71,77]$; [63, 64, 66, 74]. The remaining one-third focused on treatment effectiveness $(n=4)$
[24, 69, 73, 75]; effectiveness-implementation $(\mathrm{n}=3)$ [29, $62,72]$ or implementation research $(n=3)[59,61,67]$. One effectiveness-implementation study also evaluated client access and staff access and acceptability [29], and another study evaluated implementation and client and staff acceptability [59].

The majority of studies $(\mathrm{n}=17 ; 60 \%)$ reported on western treatment approaches $[24,29,30,54-61,68$, $70-73,75]$, with only 3 reporting specifically on cultural approaches $(\mathrm{n}=3)$ [74, 76, 77] for addressing 


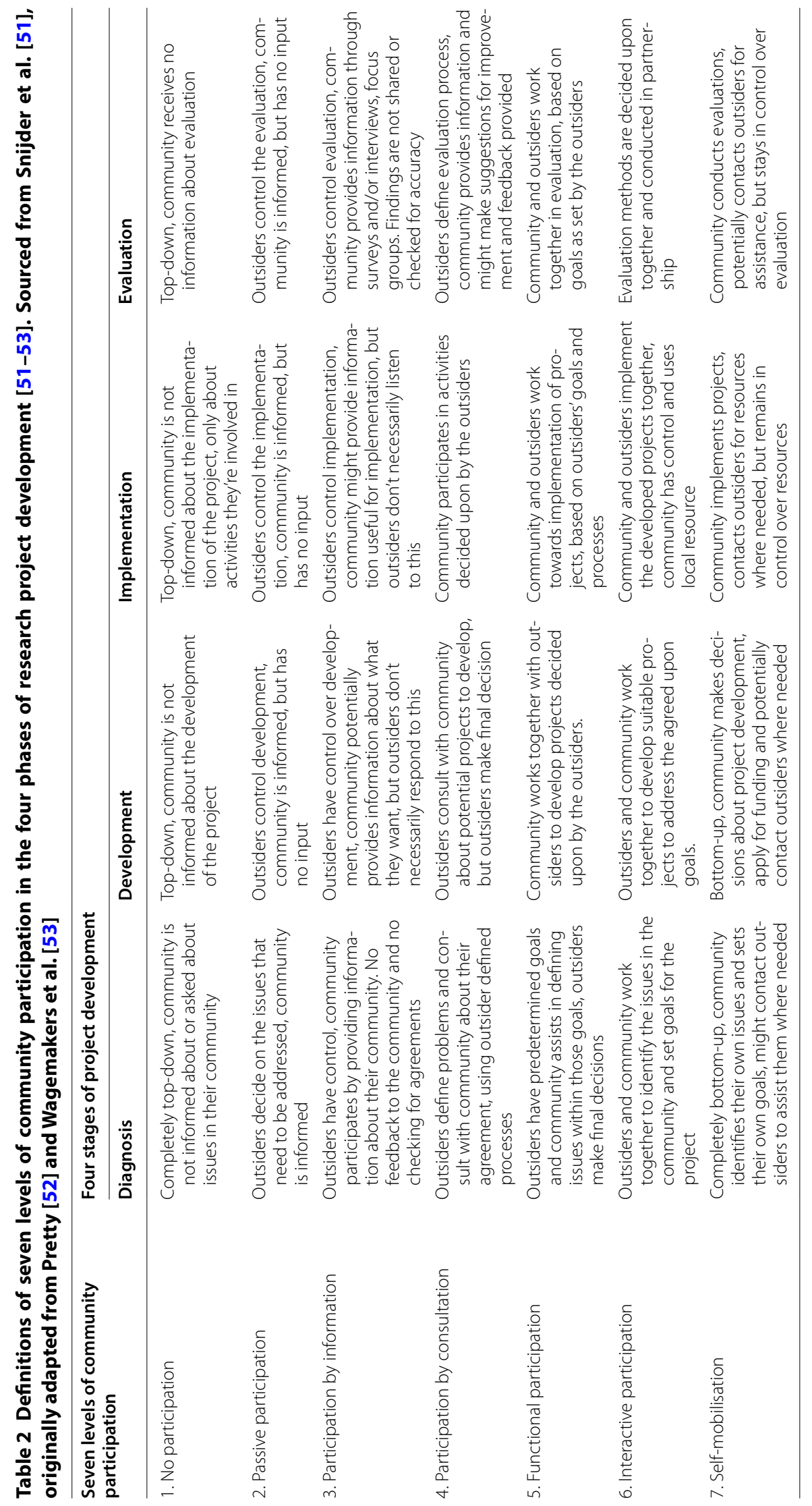


Table 3 Scope of the literature meeting inclusion criteria $(\mathbf{n}=28)$

\begin{tabular}{|c|c|c|c|c|c|}
\hline Author (year) & $\begin{array}{l}\text { Country } \\
\text { (Indigenous } \\
\text { population) }\end{array}$ & $\begin{array}{l}\text { Primary focus } \\
\text { of study }^{\text {a }}\end{array}$ & $\begin{array}{l}\text { Description of alcohol } \\
\text { problem treated }\end{array}$ & $\begin{array}{l}\text { Strategy: } \\
\text { Western/ } \\
\text { cultural/both }\end{array}$ & $\begin{array}{l}\text { Intervention/therapy } \\
\text { studied }\end{array}$ \\
\hline \multicolumn{6}{|l|}{ Treatment effectiveness } \\
\hline $\begin{array}{l}\text { Savard }[75]^{b} \\
(1968)\end{array}$ & $\begin{array}{l}\text { USA } \\
\text { (Navaho) }\end{array}$ & Treatment effectiveness & Alcoholism & Western & $\begin{array}{l}\text { Pharmacotherapy } \\
\text { (disulfiram) }^{c}\end{array}$ \\
\hline $\begin{array}{l}\text { Ferguson [73] } \\
\text { (1970) }\end{array}$ & $\begin{array}{l}\text { USA } \\
\text { (Navaho) }\end{array}$ & Treatment effectiveness & Alcoholics & Western & $\begin{array}{l}\text { Pharmacotherapy } \\
\text { (disulfiram) })^{c}\end{array}$ \\
\hline $\begin{array}{l}\text { O'Malley et al. [24] } \\
\text { (2008) }\end{array}$ & $\begin{array}{l}\text { USA } \\
\text { (American Indian/Alaska } \\
\text { Native) }\end{array}$ & Treatment effectiveness & Alcohol dependence & Western & $\begin{array}{l}\text { Pharmacotherapy (nal- } \\
\text { trexone) }\end{array}$ \\
\hline $\begin{array}{l}\text { Venner et al. [69] } \\
\text { (2016) }\end{array}$ & $\begin{array}{l}\text { USA } \\
\text { (American Indian/Alaska } \\
\text { Native) }\end{array}$ & Treatment effectiveness & $\begin{array}{l}\text { Substance use disorder } \\
\text { and alcohol abuse/ } \\
\text { dependence }\end{array}$ & Both & $\begin{array}{l}\text { MICRA (CBT)/cultural } \\
\text { practices }\end{array}$ \\
\hline \multicolumn{6}{|l|}{ Implementation research } \\
\hline $\begin{array}{l}\text { Kahn and Fua [72] } \\
\quad(1992)\end{array}$ & $\begin{array}{l}\text { Australia } \\
\text { (Aboriginal) }\end{array}$ & $\begin{array}{l}\text { Effectiveness-implemen- } \\
\text { tation }\end{array}$ & Alcoholism & Western & $\begin{array}{l}\text { Counsellor training as } \\
\text { therapy }\end{array}$ \\
\hline $\begin{array}{l}\text { Clifford and Shakeshaft } \\
\text { [59] (2011) }\end{array}$ & $\begin{array}{l}\text { Australia } \\
\text { (Aboriginal and or Torres } \\
\text { Strait Islander) }\end{array}$ & $\begin{array}{l}\text { Implementation } \\
\text { research; } \\
\text { staff and client accept- } \\
\text { ability }\end{array}$ & At-risk drinkers & Western & $\mathrm{Bl}$ \\
\hline $\begin{array}{l}\text { Clifford et al. [61] } \\
\text { (2013) }\end{array}$ & $\begin{array}{l}\text { Australia } \\
\text { (Aboriginal and or Torres } \\
\text { Strait Islander) }\end{array}$ & $\begin{array}{l}\text { Implementation } \\
\text { research }\end{array}$ & At-risk of alcohol-related & Western & $\mathrm{Bl}$ \\
\hline $\begin{array}{l}\text { D'Abbs et al. [62] } \\
\text { (2013) }\end{array}$ & $\begin{array}{l}\text { Australia } \\
\text { (Aboriginal) }\end{array}$ & $\begin{array}{l}\text { Effectiveness-implemen- } \\
\text { tation }^{d}\end{array}$ & Alcohol problems & Both $^{e}$ & $\begin{array}{l}\text { CBT/social-cultural sup- } \\
\text { port/pharmacotherapy } \\
\text { (naltrexone) }\end{array}$ \\
\hline Lovett et al. [67] (2014) & $\begin{array}{l}\text { Australia } \\
\text { (Aboriginal and Torres } \\
\text { Strait Islander) }\end{array}$ & $\begin{array}{l}\text { Implementation } \\
\text { research }\end{array}$ & Problematic alcohol use & Both & $\begin{array}{l}\text { Culturally appropriate } \\
\text { introduction to Bl and } \\
\text { case management }\end{array}$ \\
\hline Brett et al. [29] (2017) & Australia (Aboriginal) & $\begin{array}{l}\text { Effectiveness-implemen- } \\
\text { tationd; } \\
\text { client access; staff and } \\
\text { client acceptability }\end{array}$ & Alcohol dependence & Western & $\begin{array}{l}\text { 'Home detox' } \\
\text { (ambulatory withdrawal) }\end{array}$ \\
\hline \multicolumn{6}{|c|}{ Treatment access and/or accessibility } \\
\hline $\begin{array}{l}\text { Hall }[74] \\
(1986)\end{array}$ & $\begin{array}{l}\text { USA } \\
\text { (American Indian) }\end{array}$ & $\begin{array}{l}\text { Client access; staff } \\
\text { acceptability }\end{array}$ & Alcoholism & Cultural & Cultural practices \\
\hline Brady et al. [70] (1998) & $\begin{array}{l}\text { Australia } \\
\text { (Aboriginal) }\end{array}$ & Staff acceptability & Alcohol problems & Western & $\mathrm{Bl}$ \\
\hline $\begin{array}{l}\text { Huriwai et al. [76] } \\
\text { (2000) }\end{array}$ & $\begin{array}{l}\text { New Zealand } \\
\text { (Māori) }\end{array}$ & Client acceptability & Alcohol problems & Cultural & Cultural practices \\
\hline $\begin{array}{l}\text { Robertson et al. [77] } \\
\text { (2001) }\end{array}$ & $\begin{array}{l}\text { New Zealand } \\
\text { (Māori) }\end{array}$ & Staff acceptability & Alcohol problems & Cultural & Cultural practices \\
\hline Brady et al. [71] (2002) & $\begin{array}{l}\text { Australia } \\
\text { (Aboriginal) }\end{array}$ & $\begin{array}{l}\text { Staff acceptability and } \\
\text { staff perception of } \\
\text { client acceptability }\end{array}$ & Hazardous alcohol use & Western & $\mathrm{Bl}$ \\
\hline $\begin{array}{l}\text { DeVerteuil and Wilson } \\
\text { [63] (2010) }\end{array}$ & $\begin{array}{l}\text { Canada } \\
\text { (Aboriginal) }\end{array}$ & $\begin{array}{l}\text { Client access; staff } \\
\text { acceptability }\end{array}$ & Alcohol use problems & Both & Cultural practices \\
\hline $\begin{array}{l}\text { Panaretto et al. [68] } \\
\text { (2010) }\end{array}$ & $\begin{array}{l}\text { Australia } \\
\text { (Aboriginal and Torres } \\
\text { Strait Islander) }\end{array}$ & $\begin{array}{l}\text { Staff perceptions of } \\
\text { client access; staff } \\
\text { acceptability }\end{array}$ & $\begin{array}{l}\text { Alcohol abuse and } \\
\text { alcohol harms }\end{array}$ & Western & $\mathrm{Bl}$ \\
\hline $\begin{array}{l}\text { Allan [54] } \\
(2010)\end{array}$ & $\begin{array}{l}\text { Australia } \\
\text { (Aboriginal and or Torres } \\
\text { Strait Islander) }\end{array}$ & $\begin{array}{l}\text { Staff access and accept- } \\
\text { ability }\end{array}$ & Problematic alcohol use & Western & $\mathrm{Bl}$ \\
\hline $\begin{array}{l}\text { Gone [64] } \\
\text { (2011) }\end{array}$ & $\begin{array}{l}\text { Canada } \\
\text { (Algonquian) }\end{array}$ & $\begin{array}{l}\text { Client access; staff and } \\
\text { client acceptability }\end{array}$ & Alcoholism & Both & $\begin{array}{l}\text { Counselling/cultural } \\
\text { practices }\end{array}$ \\
\hline $\begin{array}{l}\text { Allan and Campbell } \\
\text { [55] (2011) }\end{array}$ & $\begin{array}{l}\text { Australia } \\
\text { (Aboriginal) }\end{array}$ & $\begin{array}{l}\text { Client access and } \\
\text { acceptability }\end{array}$ & Harmful substance use & Western & MI/BI/Counselling \\
\hline
\end{tabular}


Table 3 (continued)

\begin{tabular}{|c|c|c|c|c|c|}
\hline Author (year) & $\begin{array}{l}\text { Country } \\
\text { (Indigenous } \\
\text { population) }\end{array}$ & $\begin{array}{l}\text { Primary focus } \\
\text { of study }^{a}\end{array}$ & $\begin{array}{l}\text { Description of alcohol } \\
\text { problem treated }\end{array}$ & $\begin{array}{l}\text { Strategy: } \\
\text { Western/ } \\
\text { cultural/both }\end{array}$ & $\begin{array}{l}\text { Intervention/therapy } \\
\text { studied }\end{array}$ \\
\hline $\begin{array}{l}\text { Clifford et al. [60] } \\
\text { (2012) }\end{array}$ & $\begin{array}{l}\text { Australia } \\
\text { (Aboriginal and or Torres } \\
\text { Strait Islander) }\end{array}$ & Staff acceptability & Risky drinking & Western & $\mathrm{Bl}$ \\
\hline $\begin{array}{l}\text { Conigrave et al. [30] } \\
\text { (2012) }\end{array}$ & $\begin{array}{l}\text { Australia } \\
\text { (Aboriginal) }\end{array}$ & $\begin{array}{l}\text { Client accessibility/ } \\
\text { awareness }\end{array}$ & $\begin{array}{l}\text { Alcohol problems and } \\
\text { alcohol use disorder }\end{array}$ & Western & $\mathrm{Bl}$ \\
\hline $\begin{array}{l}\text { Legha and Novins [66] } \\
\text { (2012) }\end{array}$ & $\begin{array}{l}\text { USA } \\
\text { (American Indian/Alaska } \\
\text { Native) }\end{array}$ & $\begin{array}{l}\text { Client access; staff } \\
\text { acceptability }\end{array}$ & Alcohol abuse & Both & Cultural practices \\
\hline $\begin{array}{l}\text { Calabria et al. [57] } \\
\text { (2013) }\end{array}$ & $\begin{array}{l}\text { Australia } \\
\text { (Aboriginal) }\end{array}$ & Client acceptability & Alcohol-related harms & Western & CBT (CRA + CRAFT) \\
\hline $\begin{array}{l}\text { Lee et al. [65] } \\
\text { (2013) }\end{array}$ & $\begin{array}{l}\text { Australia } \\
\text { (Aboriginal) }\end{array}$ & $\begin{array}{l}\text { Client access and } \\
\text { acceptability }\end{array}$ & Alcohol use disorder & Both & Women's group (cultural) \\
\hline $\begin{array}{l}\text { Brett et al. [56] } \\
\text { (2014) }\end{array}$ & $\begin{array}{l}\text { Australia } \\
\text { (Aboriginal and Torres } \\
\text { Strait Islander) }\end{array}$ & $\begin{array}{l}\text { Staff perspective of } \\
\text { treatment acceptability } \\
\text { and accessibility }\end{array}$ & Alcohol dependence & Western & $\begin{array}{l}\text { 'Home detox' (ambulatory } \\
\text { withdrawal) }\end{array}$ \\
\hline $\begin{array}{l}\text { Calabria et al. [58] } \\
\text { (2014) }\end{array}$ & $\begin{array}{l}\text { Australia } \\
\text { (Aboriginal) }\end{array}$ & Staff acceptability & Alcohol-related harms & Western & CBT (CRA + CRAFT) \\
\hline $\begin{array}{l}\text { Hirchak et al. [31] } \\
\text { (2018) }\end{array}$ & $\begin{array}{l}\text { USA } \\
\text { (American Indian/Alaska } \\
\text { Native) }\end{array}$ & Client acceptability & Alcohol use disorders & Both & $\begin{array}{l}\text { Contingency manage- } \\
\text { ment/ } \\
\text { cultural practices }\end{array}$ \\
\hline
\end{tabular}

a Studies are ordered in tables according to their focus and year of publication

${ }^{b}$ Results for this trial of disulfiram therapy were gathered from the background section of the cited publication (published 1964). The cited source for the data was an unpublished conference presentation by the same author who was involved with conducting the trial. Sufficient detail was presented to allow the methods to be described. This was cross-checked against a thesis by the same author. Data was not published elsewhere in refereed journals. Given the scarcity of quantitative data it was decided to include this study

c Both disulfiram trials required in-patient detoxification and commencement of therapy before participants were discharged to continue disulfiram therapy as outpatients. As part of the initial hospitalisation, after commencement of disulfiram, a "challenge dose" of alcohol was administered to measure the severity of reactions in a controlled environment. This is not standard practice today

d Primary focus was implementation but there were outcome results from a series of patients in these studies

e This intervention is mostly western, cultural care was planned but not delivered due to practical constraints

unhealthy alcohol use. Eight studies reported on both [31, 62-67, 69]. The balance of western compared to cultural approaches varied by country. Of the Australian publications, the majority $(n=13 / 17)$ examined use or implementation of a western approach, most often BI $[30,54-61,68,70-72]$. The two studies from New Zealand solely focused on the importance and acceptability of culture in alcohol care [76, 77]. Half of US-based studies $(n=4 / 8)$ included cultural approaches $[31,66,69,74]$. The two Canadian studies explored bicultural approaches $[63,64]$.

\section{Study outcomes}

\section{Treatment effectiveness outcomes}

Seven studies in total measured alcohol consumption (e.g. frequency of 'binges' and duration of abstinence) $[24,29,62,69,72,73,75]$. These were the only studies that examined effectiveness, and include both treatment effectiveness and effectiveness-implementation studies (Table 3).

Of these seven studies, one was a double-blind, randomised-controlled trial (RCT) of naltrexone alone and in combination with sertraline, conducted with Alaska Natives [24]. Alcohol-related consequences were significantly lower (38\%) in the naltrexone monotherapy group compared with placebo $(72 \% ; p=0.026)$. There was a high abstinence rate in both the naltrexone only and the placebo group over 68 weeks (percentage days abstinent of $96.6 \% \pm 2.9 \%$ vs $88.8 \% \pm 3.0 \%$ respectively). Differences between the two naltrexone conditions were not significant on any measure. However, the small sample $(n=68)$, may not have given sufficient power to detect moderate effect sizes.

Two of the older studies were trials of disulfiram on Navaho country with several clan groups. In both trials, patients were administered an alcohol challenge in hospital after starting disulfiram. The first, in 1968, reported over half of the participants $(n=16 / 30)$ maintained abstinence at 6-18 months after detoxification and commencement of disulfiram. Another seven participants $(n=7 / 30)$ had relapsed but resumed disulfiram therapy and were again abstinent at the post-intervention assessment [75]. Study participants reported disulfiram as helpful in avoiding social pressure to drink. The second trial 


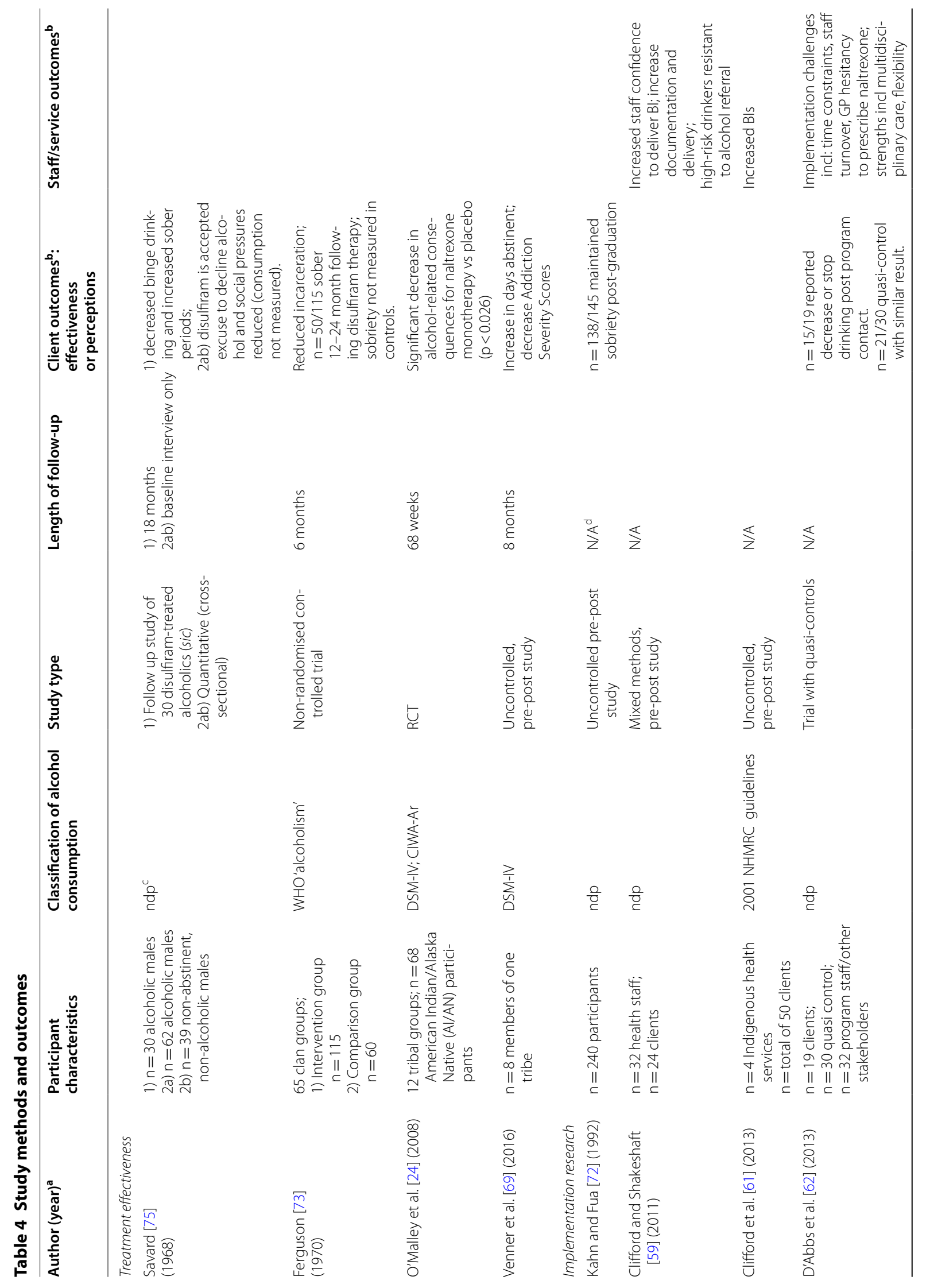




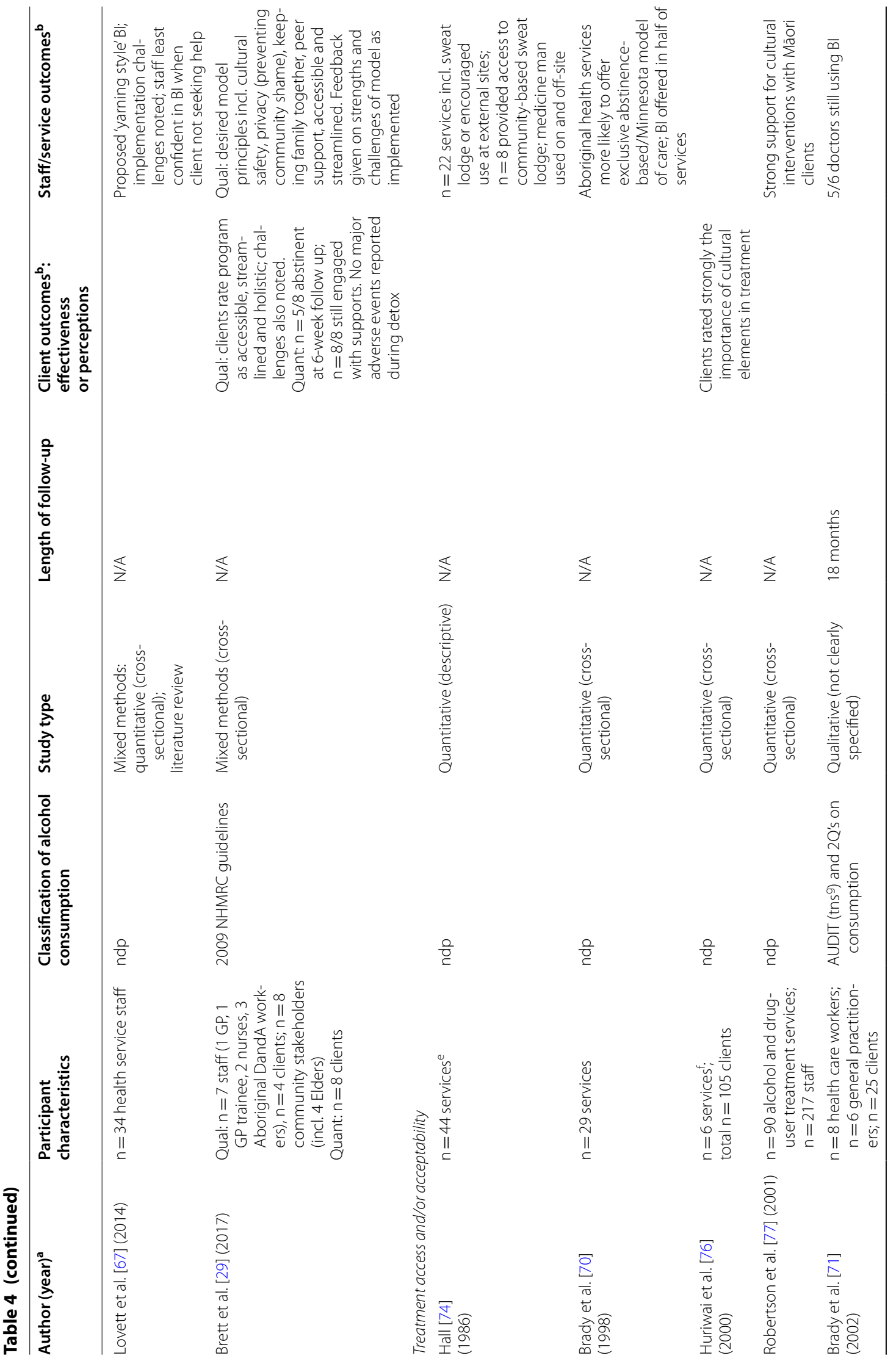




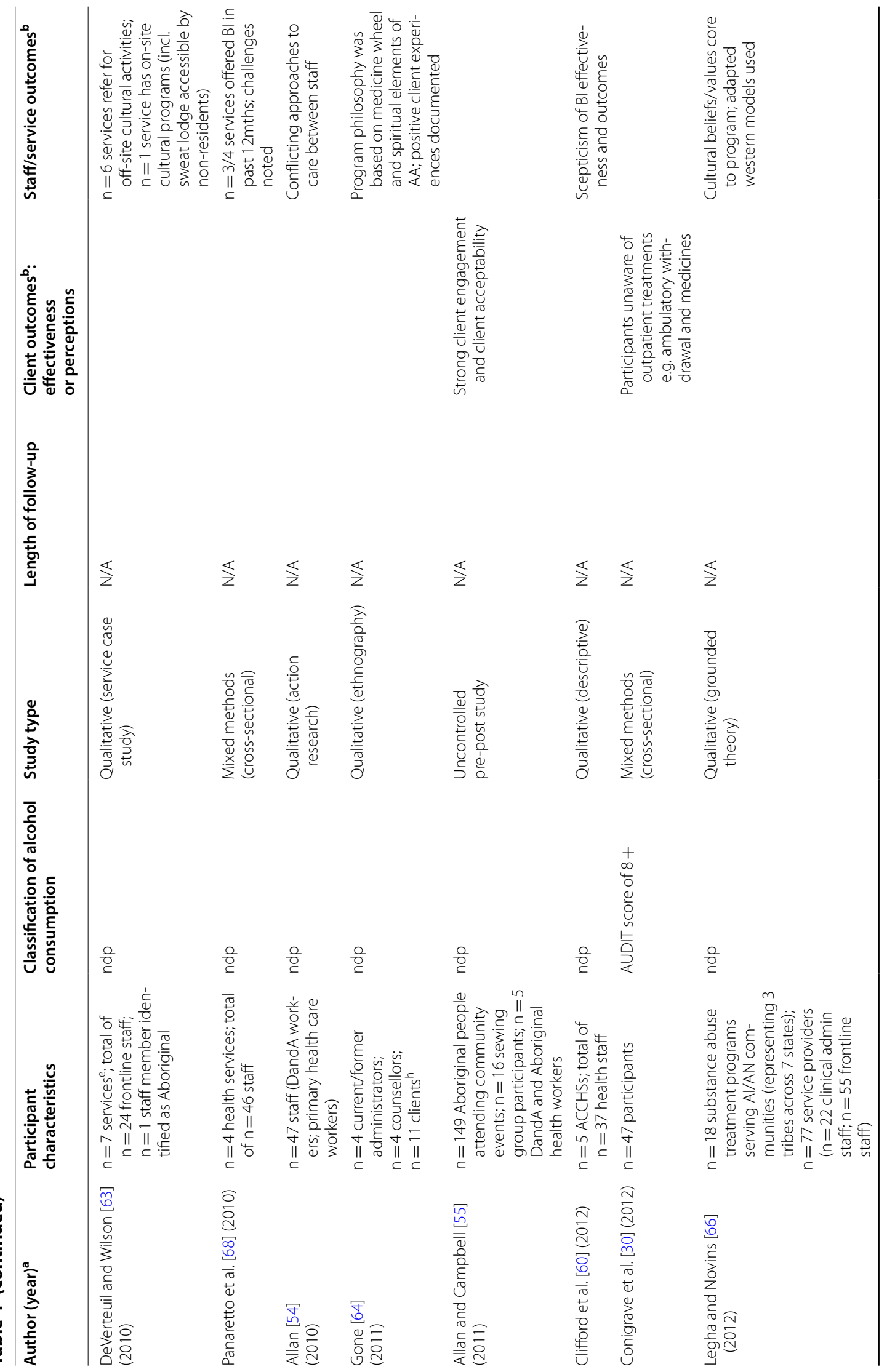




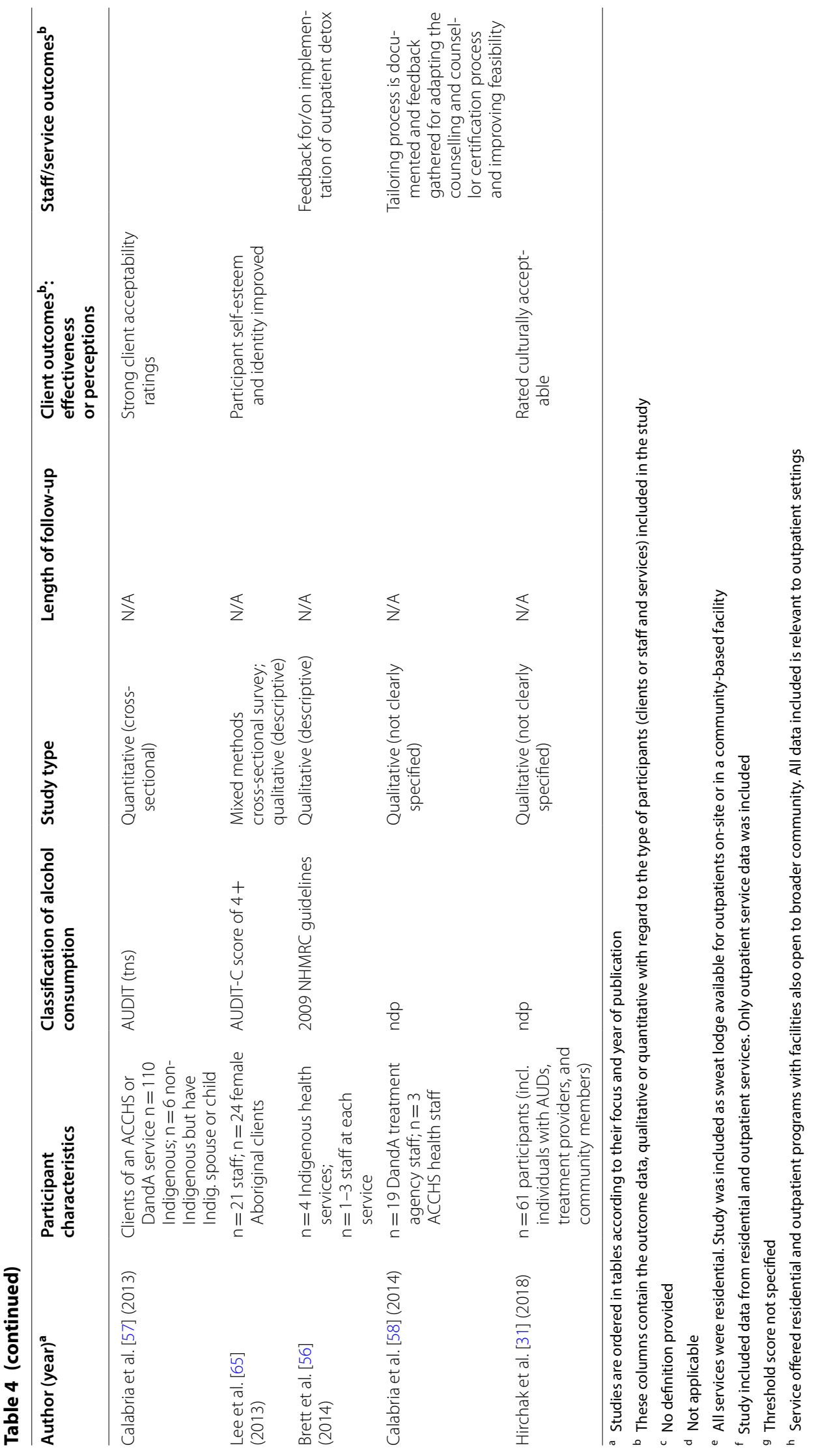


of disulfiram in 1970, reported that nearly half of participants $(n=50 / 115)$ were abstinent at $12-24$ months [73]. During the 18-month treatment period the number of arrests for drunkenness (sic) decreased by $78 \%$ compared with the prior 18 months. Neither study had a true control group and alcohol consumption was not measured in their comparison groups.

Two studies trialled interventions in Australian Aboriginal Community Controlled Health Services (ACCHS). The first (uncontrolled) study examined a multi-disciplinary alcohol intervention, including naltrexone [62]. However, the untreated comparison group reduced their drinking at similar rates to the participants who received the intervention. The second study documented the development of a 'home detox' (ambulatory withdrawal management) program and the outcomes with $n=8$ clients [29]. The program typically ran for 5 days with daily administration of diazepam (weaning dose) and thiamine in combination with counselling and a relapse prevention plan. Home visits and transport were provided. At the 6-week follow up over half $(n=5 / 8)$ of the clients remained abstinent (including one who had transitioned to residential rehabilitation). All eight clients were still engaged with service supports. No major adverse events were reported during detox.

The (non-random, uncontrolled) 'counsellor training as therapy' study [72] reported a high rate of abstinence at 24 months (95\% of participants). Individuals with known past 'very severe alcohol abuse' were nominated to take part in the training by community leaders or existing treatment program staff. Potential participants were deemed eligible based also on their current interest, level of motivation and perceived capacity to complete the program. Lastly, an uncontrolled pilot study that used a culturally adapted form of MICRA (Motivational Interviewing and Community Reinforcement Approach) [69] reported an increase in days abstinent and a decrease in addiction severity scores (using a culturally adapted version of the Addiction Severity Index, ASI-NA) at 8-month follow-up compared to the pre-treatment period and baseline respectively.

\section{Client awareness or perceptions}

Client awareness or perceptions were investigated regarding three domains: acceptability of a treatment approach; awareness of treatments and perceived accessibility; and opinions on the importance of cultural elements in care, and documentation of cultural treatment content.

Three Australian studies assessed and documented the acceptability of an intervention with clients $[29,55$, 57]. Tailoring to optimise cultural appropriateness and acceptability was conducted in two other studies $[31,58]$.
Both of these interventions were reported as acceptable after tailoring. Community-based education and group brief intervention was piloted in one study with Aboriginal Australians [30]. In this study, participants were found to be unaware of non-residential treatment options such as ambulatory withdrawal management and relapse prevention medicines. Client acceptability and accessibility of one such non-residential option were explored in a separate Australian study from the perspective of staff and service providers [56]. Staff perceived ambulatory withdrawal management as a viable and underutilised approach, and feedback for optimal implementation was documented (Table 4). In a third Australian study focusing on ambulatory withdrawal [29] (described in the treatment effectiveness section), participants reported being 'satisfied' or 'very satisfied' with the program, would repeat it if needed, and would recommend it to a friend. Clients in this study reported preferring ACCHS over mainstream services. Cultural appropriateness was a core aim in developing the pilot program of this western treatment.

Two studies explored cultural practices in treatment, one with First Nation Americans and the other with Māori peoples [64, 76]. Clients and clinical staff rated cultural elements as highly important in both studies (Table 4).

\section{Staff and service outcomes or perceptions}

Fourteen studies included data on treatment implementation outcomes (implementation studies) or staff perceptions of the acceptability and accessibility of alcohol treatments [29, 54, 59-61, 63, 64, 66-68, 70, 71, 74, 77]. Most of these studies examined brief intervention (BI) $(n=6 / 14)$ [59-61, 67, 68, 71]. Training and outreach support were found to increase staff confidence to deliver BI [59] and resulted in increased BI delivery rates [61]. Two studies reported on perceived barriers to delivering BIs. These included: scepticism of BI effectiveness [60]; time pressure in the clinical environment, and high staff turnover [68]. It was also noted in a survey of $(n=29)$ Australian services, that service philosophy (abstinence as a goal versus moderated drinking) dictated BI delivery [70]. Lastly, one study described implementation of a culturally-tailored BI [67].

Five studies presented data from staff and clients on service delivery of cultural or bicultural treatment approaches [63, 64, 66, 74, 77]. Of these, three studies documented the importance of cultural interventions; this included two staff surveys $[66,77]$ and one case study [64]. The surveys reported: strong support from nonIndigenous and First Nation clinicians to use cultural interventions to increase client wellbeing and engagement [77]. Also, that services with cultural beliefs at their 
core (i.e. holistic views of health; spiritual care; importance of kinship etc.) could implement traditional healing interventions alongside western approaches when those western approaches had been tailored for the local First Nations communities [66]. The case-study described a largely cultural model of care centred on the medicinewheel philosophy [64]. However, this treatment approach also included spiritual elements of Alcoholics Anonymous. The two other studies investigating service delivery of cultural and bicultural interventions reported the 'sweat-lodge' as the most frequently used therapy $[63,74]$. Other cultural activities were also described at one residential service which allowed access for out-patients [63]. Staff attitudes towards the integration of cultural healing interventions within a standard western-treatment facility varied. Some staff at that service expressed scepticism and devalued cultural elements in care. This was most frequently expressed by staff in facilities which did not provide sweat-lodge access on-site but outsourced cultural activities to community organisations [63].

\section{Study quality}

There were only two controlled trials (one blinded RCT [24] and one non-randomised controlled trial [73]). The remainder of the quantitative studies had no control group $(\mathrm{n}=5)$ [55, 61, 62, 69, 72]. Most studies were of moderate quality when examined with the AXIS critical appraisal tool [50].

Objectives and aims were clearly described, and study design was appropriate for the stated aims in two-thirds of studies ( $\mathrm{n}=25,89 \% ; \mathrm{n}=20,71 \%$ respectively) [24, 2931, 55-61, 63-74, 76, 77]; [24, 29-31, 54, 56-60, 63-68, 70-77]. Study populations were clearly defined $(n=25$, $89 \%)$ and taken from samples which were likely representative in most studies $(\mathrm{n}=23,82 \%)[24,29-31,54$, 57-70, 72-77]; [24, 29-31, 54, 57-63, 65-68, 70, 72-77]. However, most studies $(\mathrm{n}=25,89 \%)$ did not describe non-responders or missing data $[24,29-31,54-59$, 61-65, 68-77]. Methods were insufficiently described in a third of studies $(\mathrm{n}=10,36 \%)$ to allow replication [30, $31,54-56,62,64,66,71,75]$. Basic data (e.g. demographics) were not described in nearly half of studies $(n=13$, 46\%) [54-56, 59-64, 70, 71, 74, 75], of which, nine were published in the last decade [54-56, 59-64]. Discussion and conclusions did not appear justified by the results in a quarter of studies $(n=6,21.5 \%)[24,54-56,61,69]$ and ethical approval was not mentioned in just under a third of studies $(n=9,32 \%)[54,63,64,70-75]$.

\section{Extent of community participation}

Community participation by First Nations peoples varied (Table 5). The highest levels of participation (Levels 5 to 7) were found in both the 'diagnosis' phase of the research, and the 'development' phase, with nine studies $(32 \%)$ each $[24,29-31,62,65,69,73,75]$; [29-31, 62, $64,65,69,73]$. This was followed by the 'implementation' phase $(\mathrm{n}=7$; 25\%) [29-31, 62, 64, 65, 73]. Four studies scored highly in all of the first three phases (14\%) [30, 31, $62,73]$. Only one study scored highly in all four phases [29]. Participation was described with insufficient detail to be assessed in twelve studies (43\%) [56-61, 63, 67, 68, $74,76,77]$.

\section{Discussion}

This is the first systematic review of treatments for unhealthy alcohol use for First Nations peoples that are feasible in or from primary care settings. Publications from Australia, New Zealand, Canada, and the USA were considered. The 28 included studies report on all aspects of standard alcohol treatment, from brief intervention to ambulatory withdrawal management, relapse-prevention medicines, as well as on cultural treatments. Between countries, we found Australian studies were heavily focused on early intervention for non-dependent drinkers while in the USA there was greater emphasis on interventions for alcohol use disorders, including dependence. Terminology used to classify participant alcohol use varied. Only seven studies attempted to measure intervention effectiveness. Of these, there was only one RCT. Accordingly, insight into what approaches lead to the best clinical outcomes for First Nations clients is limited. Furthermore, quality was negatively impacted by low levels of community participation in research processes and often a lack of transparency in this regard. Large effectiveness studies, conducted in close partnership with communities, are required to inform best practice with these populations.

\section{Western approaches}

Western approaches were studied in a variety of ways. Some trialled the standard western treatment approach, while others engaged First Nations clients or staff in tailoring it for the Indigenous context. Western approaches were also used in conjunction with cultural therapies, sometimes as a bicultural strategy, and other times the cultural elements were outsourced to community organisations as 'clip-on' elements of care.

Brief intervention was the most studied approach; however, no study measured its effectiveness. Effective client-clinician communication is at the core of BI and is likely impacted by the communication preferences and cultural protocols of First Nations peoples [78, 79]. The one study which implemented a culturally-influenced version of BI [67], did not describe the development of the approach. Tailoring and implementation studies are 
Table 5 Level of community participation across the development of each study

\begin{tabular}{|c|c|c|c|c|}
\hline \multirow[t]{2}{*}{ Author (year) } & \multicolumn{4}{|c|}{ Four stages of project development } \\
\hline & Diagnosis & Development & Implementation & Evaluation \\
\hline \multicolumn{5}{|l|}{ Treatment effectiveness } \\
\hline Savard [75] (1968) & $5-6$ & $-^{\mathrm{a}}$ & - & - \\
\hline Ferguson [73] (1970) & 6 & $4-5$ & $4-5$ & - \\
\hline O'Malley et al. [24] (2008) & 5 & 4 & 4 & - \\
\hline Venner et al. [69] (2016) & 6 & 5 & 4 & 4 \\
\hline \multicolumn{5}{|l|}{ Implementation research } \\
\hline Kahn and Fua [72] (1992) & 3 & - & 3 & - \\
\hline Clifford and Shakeshaft [59] (2011) & - & - & - & - \\
\hline Clifford et al. [61] (2013) & - & - & - & - \\
\hline D'Abbs et al. [62] (2013) & 7 & 7 & 7 & 4 \\
\hline Lovett et al. [67] (2014) & - & - & - & - \\
\hline Brett et al. [29] (2017) & $6-7$ & 6 & 7 & 6 \\
\hline \multicolumn{5}{|l|}{ Treatment access and/or acceptability } \\
\hline Hall [74] (1986) & - & - & - & - \\
\hline Brady et al. [70] (1998) & 1 & 1 & 1 & 1 \\
\hline Huriwai et al. [76] (2000) & - & - & - & - \\
\hline Robertson et al. [77] (2001) & - & - & - & - \\
\hline Brady et al. [71] (2002) & 3 & 3 & 3 & - \\
\hline DeVerteuil and Wilson [63] (2010) & - & - & - & - \\
\hline Panaretto et al. [68] (2010) & - & - & - & - \\
\hline Allan [54] (2010) & 3 & - & - & - \\
\hline Gone [64] (2011) & - & $4-5$ & 5 & - \\
\hline Allan and Campbell [55] (2011) & 2 & - & - & - \\
\hline Clifford et al. [60] (2012) & - & - & - & - \\
\hline Conigrave et al. [30] (2012) & 6 & 6 & 6 & - \\
\hline Legha and Novins [66] (2012) & 2 & 2 & - & - \\
\hline Calabria et al. [57] (2013) & - & - & - & - \\
\hline Lee et al. [65] (2013) & 7 & 6 & 5 & 4 \\
\hline Brett et al. [56] (2014) & - & - & - & - \\
\hline Calabria et al. [58] (2014) & - & - & - & - \\
\hline Hirchak et al. [31] (2018) & 5 & 5 & 5 & 4 \\
\hline
\end{tabular}

a Insufficient data to apply assessment criteria

needed to optimise BI delivery and should record client perceptions of acceptability, as well as effectiveness.

Ambulatory withdrawal management was examined in two Australian studies in relation to Aboriginal Community Controlled Health Services. For carefully selected individuals, this approach may help increase accessibility and acceptability of withdrawal management. The research also demonstrated how community partnerships can be a part of developing, running and evaluating such programs within a primary health care service.

A small number of studies trialled alcohol relapseprevention medicines. The RCT of naltrexone reported significant reduction in alcohol-related consequences compared to placebo despite low participant numbers
[24]. Inclusion criteria for the trial may have been a barrier for First Nation people's participation as interested persons were required to provide confirmation of "tribal enrolment" or a "Certificate of Indian Blood". Of the 28 included studies, this was the only study where verification of First Nations status was discussed. This may have been due to the study's exploratory aim of looking at predicted responses to treatment based on genetic traits. Consultation with community partners may help to respectfully decide on terms of participation and reduce barriers to participation in clinical trials.

The two other studies involving relapse prevention medicines trialled disulfiram. Both were performed half a century ago (1968 and 1970) and involved administration 
of a test dose of alcohol to precipitate a reaction. This is not standard practice today and would raise ethical concerns. Due to the scarcity of relapse prevention medicine trials with First Nations peoples, it was decided to include these studies. Disulfiram is not as frequently prescribed as it once was, due to concerns over serious adverse reactions in the event of relapse to drinking and debate over its effectiveness, particularly with unsupervised dosing. Despite these concerns, disulfiram is still prescribed internationally for carefully selected and voluntary patients [80]. In Australia, lack of government subsidies on the cost has also been identified as a barrier to its use [81]. The models of support offered alongside disulfiram therapy in these two studies appeared to be culturally tailored and progressive for their era. However, given the studies were conducted over 50 years ago, client acceptability data may need to be re-examined. Acamprosate, was not trialled or mentioned in any study. In contrast, amongst the general population both acamprosate and naltrexone have been trialled extensively.

Underutilisation of these medicines is a populationwide trend, although a range of social determinants may see First Nations peoples being less likely to access alcohol pharmacotherapy than non-Indigenous populations $[82,83]$. Based on the included studies, medicines to prevent relapse seem acceptable within a culture-informed framework [24, 56]. Methods to increase awareness of the medicines and their availability through primary care services, could be considered in future research [30].

\section{Cultural and bicultural approaches}

Cultural healing practices and spiritual customs were a major theme in this review. Traditional healing approaches have also appeared in other areas of First Nation's health research, responding to the communities' call-"our culture is our treatment" [17, 42, 84, 85]. The integration of cultural protocols and traditional therapies into primary health care has been associated with the movement for cultural reclamation. These themes were highlighted in one of the earliest included studies [74]. Along with innovations in treatment content and tailoring of delivery to increase acceptability and accessibility for minorities, community leaders are pushing for control over what is studied and how research questions are framed [86]. First Nations Elders are resisting the framing of research in deficit-based rhetoric, in favour of strength-based approaches and stories of resilience [87-89]. With this paradigm shift comes opportunities to create knowledge that incorporates the best of western, evidence-based practice with traditional knowledges, forming a third stream valuable in both spheres. This concept has been articulated in "two-eyed seeing" and
"Ganma" philosophies [90, 91], from Canada and Yolngu Nation (Australia) respectively.

The notion of Indigenous culture in health care is tied to holistic definitions of health. This invariably involves connectedness to family, traditional homelands, spirituality, community identity and reciprocal relationships $[26,92,93]$. In research of the general population, factors such as connectedness have also been identified as important on the recovery journey for addictions [94, 95]. Likewise, connectedness has been identified as a protective factor against AUDs by First Nations peoples [66, $86,96]$.

Overarching health policy has recognised the need for culturally-informed and tailored health care [38-40, 97]. However, cultural and bicultural therapies are still largely unconsidered in the national alcohol treatment guidelines of all four included countries [16, 25, 98-100].

\section{Study quality}

The quality of the included studies was assessed from two lenses-from a (western) scientific lens and from a community values lens. We found reporting was more complete for scientific measures. Privacy concerns for smaller study sites may account for the lack of basic demographic data. Over half of the studies collected data through qualitative interviews and observations. While qualitative methods are important in understanding participants' thoughts and feelings, it does not allow quantification of effectiveness. Limitations also apply to pre-post treatment comparison studies, as individuals are most likely to enrol in a trial when they are highly motivated or at a point of crisis. This can falsely inflate intervention success rates, as the participants may have already been on a path to abstinence or moderated drinking (regression to the mean). While there was only one RCT, strict conditions maintained in the study environment may not hold up in many routine clinical settings. In addition to further efficacy trials, studies establishing the effectiveness of interventions for improving unhealthy alcohol use outcomes in real world settings are also needed.

Almost half of the studies did not report on community participation. This is concerning as the value of community engagement (even outside community-based, participatory study designs) is well recognised and promoted through research ethical guidelines [46, 101, 102]. According to these guidelines, best practice with First Nations communities involves meaningful engagements, where all parties are consulted before the 'problem' is defined and well before study aims and designs are planned. Reporting details of the tailoring process may be challenging due to journal word constraints. Until this is a standard requirement of reporting, onus is placed 
on researchers to succinctly describe the processes undertaken.

It is clear from the included studies, there is often a divergence of beliefs (ontology), value systems (axiology) and ways of knowing what is truth (epistemology), between the scientific and First Nation communities. This is particularly apparent with the qualitative data identified in this review. An individual's or community's experiences, perceptions and opinions (anecdotal evidence) rate low in the scientific pyramid of evidence. Meanwhile, this type of evidence has an important place in Indigenous ways of knowing [42]. Future research collaborations with First Nations communities will have to navigate these differences to generate knowledge that is valuable in both knowledge bases (pluralism).

\section{Implications}

The small number of controlled trials and effectiveness studies identified in this review, is one example of the pressing need to build on community partnerships. For example, First Nations communities have expressed concern over ethical issues with RCT designs (withholding beneficial treatment from one part of the community) [103]. Alternative study designs such as the 'steppedwedge trial' and 'wait-list control' have been approved as culturally safe by several communities [86, 104]. Given the cultural diversity within First Nations tribal groups, tailoring of treatment approaches to suit local cultural beliefs, values, protocols, and communication preferences is encouraged to promote client engagement with primary care services. Future studies could also consider attitudes to alcohol as a factor influencing treatment acceptability or delivery. Such attitudes may vary greatly between and within First Nations communities. Some communities may have a strong preference for abstinence as goal, based on past community experience of alcohol's harms, desire to avoid risk behaviours arising from non-Indigenous culture, or missionary influence $[6,105]$. For such communities, the idea of a controlled drinking goal (for non-dependent drinkers or for community) may be controversial [70]. Anecdotal evidence suggests in many communities (Indigenous and non-Indigenous) that there is a high awareness of the social harms from alcohol, but less awareness of its health effects. Any treatment efforts may need to be accompanied by sensitively conducted, community-based health promotion around alcohol.

To ensure comparability between studies, improved reporting of inclusion and exclusion criteria is needed, for example the thresholds used to define unhealthy drinking or alcohol use disorders (i.e. DSM or ICD criteria, or screening questionnaire score). Lastly, many promising treatment approaches have been abandoned after a single descriptive study, so there are many potential treatment approaches to build on and study.

\section{Limitations}

This review did not include grey literature due to practical constraints. There is likely documentation of cultural and western treatments with First Nations peoples in that literature which has been missed. Additionally, approaches such as 'managed alcohol programs' were not within the scope of this review, but have been reported to offer some promise in improving health and wellbeing outcomes [106, 107]. Community participation quality ratings may not be a true reflection on all studies' actual conduct as there may be more engagement than was recorded.

\section{Conclusions}

Overall this area is under researched with very few treatment effectiveness studies conducted, and on a limited range of therapies. Much work is needed to define approaches to unhealthy alcohol use that are most effective and acceptable for First Nations clients in a primary care setting. Trials of naltrexone and disulfiram yielded promising results, and acamprosate is yet to be studied. Cultural and bicultural approaches were generally delivered by Indigenous-specific health services or mainstream services with strong links to a First Nations community. These were found acceptable, but effectiveness outcomes have not yet been studied. Taking a strengths-based approach through community partnerships will be an essential next step if we are to produce quality research that combines scientific rigour with cultural appropriateness. First Nations researchers and Indigenous research methodologies will be an important part of this process.

\footnotetext{
Abbreviations

Al/AN: American Indian/Alaska Native; DandA: Drug and alcohol; AUD: Alcohol use disorder; USA: United States of America; DSM-IV: Diagnostic and Statistical Manual of Mental Disorders, 4th edition; BI: Brief intervention; MICRA: Motivational interviewing and community reinforcement approach; ACCHS: Aboriginal Community Controlled Health Service; ASI-NA: Addiction Severity Index adapted for use with Native Americans; CIW-Ar: Clinical Institute Withdrawal Assessment-alcohol (revised version); RCT: Randomised controlled trial; NHMRC: National Health and Medical Research Council (Australia); WHO: World Health Organization; AUDIT: Alcohol Use Disorders Identification Test; ndp: No definition provided; N/A: Not applicable; tns: Threshold score not specified; GK: Gemma Khodr; KL: Kylie Lee; JC: James Conigrave; KC: Katherine Conigrave.
}

\section{Acknowledgements}

Uncle 'Riverbank' Frank Doolan for your longstanding encouragement and guidance on cultural matters; Bernadette Carr, Donald Keast and the Dubbo Research Interest Group: thanks for your practical support and guidance in the early stages of this review; Emma Webster, Kathryn Naden and Cheryl Ah-See, one thousand thanks for making time and space to yarn on campus, boosting my spirits; Doug James and Kristie Harrison for your kind words of encouragement; CRE Indigenous Health and Alcohol: thank you to both staff and fellow 
students for your incredible support. This work is supported by the Australian National Health and Medical Research Council [NHMRC]: via a scholarship for GK from the Centre of Research Excellence in Indigenous Health and Alcohol (GNT1117198) and a project grant (GNT1105339). KC is supported by an NHMRC Practitioner Fellowship (GNT1117582).

\section{Authors' contributions}

GK: literature review, title and abstract screen, full-text screen, data extraction and interpretation, drafted paper, synthesised co-author's comments. KL: co-conceived idea for review, title and abstract screen, full-text screen, data extraction, reviewed drafts of tables, reviewed drafts of paper. JC: full-text screen, data extraction, reviewed drafts of paper. EW: reviewed drafts of paper and advised on philosophical matters in the discussion section. KC: co-conceived idea for review, adjudicated full-text screen and data extraction, reviewed drafts of tables, reviewed drafts of paper, responsible for overall integrity of the study. All authors read and approved the final manuscript.

\section{Funding}

Funding was received from the Australian National Health and Medical Research Council [NHMRC]: a scholarship for GK from the Centre of Research Excellence in Indigenous Health and Alcohol (GNT1117198), a project grant (GNT1105339), and a Practitioner Fellowship for KC (GNT1117582).

\section{Availability of data and materials}

Data for this project is stored at the University of Sydney, Camperdown 2006 New South Wales, Australia.

\section{Ethics approval and consent to participate}

No ethical approvals were sought for this study as it is a review of literature from academic databases (a systematic review).

\section{Consent for publication}

Not applicable.

\section{Competing interests}

The authors have no competing interests to declare.

\section{Author details}

${ }^{1}$ Faculty of Medicine and Health, Sydney School of Medicine; NHMRC Centre of Research Excellence in Indigenous Health and Alcohol, University of Sydney, Camperdown, NSW, Australia. ${ }^{2}$ Centre for Alcohol Policy Research, La Trobe University, Bundoora, VIC, Australia. ${ }^{3}$ Faculty of Medicine and Health, School of Rural Health, The University of Sydney, Dubbo, NSW, Australia. ${ }^{4}$ Drug Health Services, Royal Prince Alfred Hospital, Camperdown, NSW, Australia.

\section{Received: 26 November 2019 Accepted: 7 August 2020}

\section{Published online: 18 August 2020}

\section{References}

1. Stephens C, Nettleton C, Porter J, Willis R, Clark S. Indigenous peoples' health 2014; why are they behind everyone, everywhere? Lancet. 2005;366(9479):10-3. https://doi.org/10.1016/S0140-6736(05)66801-8.

2. Health promotion agency. Research and data: hazardous and risky drinking —Differences among past-year drinkers. AlcoholNZ. 2017;7(1):21-3.

3. Australian Institute of Health and Welfare. The health and welfare of Aboriginal and Torres Strait Islander peoples 2015: Determinants of Health-Alcohol. Canberra: AlHW. 2015;Cat.no.IHW147:55-57.

4. Health Canada. A statistical profile on the health of First Nations in Canada-determinants of health, 2006-2010. Ottawa: Health Canada; 2015. Cat.no.H34-193/1-2014E-PDF.

5. Australian Institute of Health and Welfare. Substance use among Aboriginal and Torres Strait Islander people: Alcohol use. Canberra: AlHW. 2011;Cat.no.IHW40:11-19.

6. Gray D, Cartwright K, Stearne A, Saggers S, Wilkes E, Wilson M. Review of the harmful use of alcohol among Aboriginal and Torres Strait Islander people. Austr Indigenous Health Bull. 2018;18:1.

7. Cunningham JK, Solomon TA, Muramoto ML. Alcohol use among Native Americans compared to whites: examining the veracity of the
'Native American elevated alcohol consumption' belief. Drug Alcohol Depend. 2016;160:65-75. https://doi.org/10.1016/j.drugalcdep .2015.12.015.

8. Conigrave JH, Lee KSK, Zheng C, Wilson S, Perry J, Chikritzhs T, et al. Drinking risk varies within and between Australian Aboriginal and Torres Strait Islander samples: a meta-analysis to identify sources of heterogeneity. Addiction. 2020. https://doi.org/10.1111/add.15015.

9. Gracey M, King M. Indigenous health part 1: determinants and disease patterns. Lancet. 2009;374(9683):65-75. https://doi.org/10.1016/s0140 -6736(09)60914-4

10. Wynne-Jones M, Hillin A, Byers D, Stanley D. Aboriginal grief and loss: a review of the literature. Austr Indigenous Health Bull. 2016;16(3):1-9.

11. King $M$, Smith $A$, Gracey $M$. Indigenous health part 2: the underlying causes of the health gap. Lancet. 2009;374(9683):76-85. https://doi. org/10.1016/S0140-6736(09)60827-8.

12. Segura $L$, Anderson P, Gual A. Optimizing the delivery of interventions for harmful alcohol use in primary healthcare: an update. Curr Opin Psychiatr. 2018;31(4):324-32. https://doi.org/10.1097/yco.0000000000 000435.

13. Williams E, Matson T, Harris A. Strategies to increase implementation of pharmacotherapy for alcohol use disorders: a structured review of care delivery and implementation interventions. Addict Sci Clin Pract. 2019;14(1):6. https://doi.org/10.1186/s13722-019-0134-8.

14. World Health Organization. Declaration of Alma-Ata. International conference on primary health care, Alma-Ata, USSR, 6-12 September 1978. Geneva:WHO. 1978. https://www.who.int/publications/almaata_decla ration_en.pdf?ua=1. Accessed 10 Feb 2020 .

15. World Health Organization (WHO), United Nations Children's Fund (UNICEF). A vision for primary health care in the 21 st century: towards universal health coverage and the Sustainable Development Goals. Geneva:WHO and UNICEF. 2018;WHO/HIS/SDS/2018.X.

16. Haber $P$, Lintzeris N, Proude E, Lopatko O. Guidelines for the treatment of alcohol problems. Canberra: CDHA. 2009. https://www.health.gov. au/sites/default/files/guidelines-for-the-treatment-of-alcohol-probl ems_0.pdf. Accessed 20 Jan 2020.

17. Rowan M, Poole N, Shea B, Gone JP, Mykota D, Farag M, et al. Cultural interventions to treat addictions in Indigenous populations: findings from a scoping study. Subst Abuse Treat Prev Policy. 2014. https://doi. org/10.1186/1747-597X-9-34.

18. Martin GW, Rehm J. The effectiveness of psychosocial modalities in the treatment of alcohol problems in adults: a review of the evidence. Can J Psychiatry. 2012;57(6):350-8. https://doi.org/10.1177/070674371205700 604.

19. Drummond C, Coulton S, James D, Godfrey C, Parrott S, Baxter J, et al. Effectiveness and cost-effectiveness of a stepped care intervention for alcohol use disorders in primary care: pilot study. Br J Psychiatry. 2009;195(5):448-56. https://doi.org/10.1192/bjp.bp.108.056697.

20. Carlebach S, Wake D, Hamilton S. Experiences of home detoxification for alcohol dependency. Nurs Stand. 2011;26(10):41-7.

21. Blondell R. Ambulatory detoxification of patients with alcohol dependence. Am Fam Physician. 2005;71(3):495-502.

22. Oslin DW, Lynch KG, Maisto SA, Lantinga LJ, McKay JR, Possemato K, et al. A randomized clinical trial of alcohol care management delivered in department of Veterans Affairs primary care clinics versus specialty addiction treatment. J Gen Intern Med. 2014;29(1):162-8. https://doi. org/10.1007/s1 1606-013-2625-8.

23. Brett J, Ivers R, Doyle M, Lawrence L, Conigrave K. Should naltrexone be the first-line medicine to treat alcohol dependence in Aboriginal and Torres Strait Islander populations? An Australian perspective. Aust Fam Physician. 2015;44(11):815-9.

24. O'Malley SS, Robin RW, Levenson AL, GreyWolf I, Chance LE, Hodgkinson CA, et al. Naltrexone alone and with sertraline for the treatment of alcohol dependence in Alaska Natives and non-natives residing in rural settings: a randomized controlled trial. Alcohol Clin Exp Res. 2008;32(7):1271-83.

25. National Institute on Alcohol Abuse and Alcoholism. Helping patients who drink too much: A clinician's guide Bethesda: NIAAA. 2005;No.073769:1-33. https://casatondemand.org/wp-content/uploads/2019/07/ helping-patients-clinicians-guide.pdf. Accessed on 10 June 2020.

26. Zubrick SR, Shepherd CCJ, Dudgeon P, Gee G, Paradies Y, Scrine C, et al. Working Together: Aboriginal and Torres Strait Islander Mental Health 
and Wellbeing Principles and Practice: Chapter 4-5. Barton: Commonwealth of Australia; 2014. p. 55-68.

27. Ministry of Health (Manatu Hauora) New Zealand Government. He Korowai Oranga Maori Health Strategy. Wellington: Ministry of Health. 2014. https://www.health.govt.nz/our-work/populations/maori-health/ he-korowai-oranga. Accessed 23 Sept 2019.

28. Ganesharajah C. Indigenous health and wellbeing: The importance of country - Native Title Research Report. Canberra: AIATSIS. 2009;1/2009. https://aiatsis.gov.au/sites/default/files/products/report_research outputs/ganesharajah-2009-indigenous-health-wellbeing-importance -country.pdf. Accessed 23 Sept 2019.

29. Brett J, Dawson A, Ivers R, Lawrence L, Barclay S, Conigrave K. Healing at home: developing a model for ambulatory alcohol "detox" in an Aboriginal community controlled health service. Int J Indig Health. 2017:12(1):24-38

30. Conigrave K, Freeman B, Caroll T, Simpson L, Lee KSK, Wade V, et al. The Alcohol Awareness Project: community education and brief intervention in an urban Aboriginal setting. Health Promot J Austr. 2012;23(3):219-25.

31. Hirchak KA, Leickly E, Herron J, Shaw J, Skalisky J, Dirks LG, et al. Focus groups to increase the cultural acceptability of a contingency management intervention for American Indian and Alaska Native Communities. J Subst Abuse Treat. 2018;90:57-63. https://doi.org/10.1016/j. jsat.2018.04.014

32. Henry BR, Houston S, Mooney GH. Institutional racism in Australian healthcare: a plea for decency. Med J Aust. 2004;180(10):517-20

33. James DB, Shakeshaft A, Munro A, Courtney RJ. A move from describing to evaluating the effectiveness of Indigenous drug and alcohol residential rehabilitation services: a systematic review. Curr Drug Abuse Rev. 2018;11:52-67. https://doi.org/10.2174/1874473711666180404123904.

34. Australian Government Department of Health. Fact Sheet: Primary Health Care. Canberra: PHN. 2018;1-2. https://www.health.gov.au/inter net/main/publishing.nsf/Content/Fact-Sheet-Primary-Health-Care. Accessed 23 Sept 2019.

35. McCambridge J, Cunningham JA. The early history of ideas on brief interventions for alcohol. Addiction. 2014;109(4):538-46. https://doi. org/10.1111/add.12458.

36. Marlatt GA, Witkiewitz K. Harm reduction approaches to alcohol use: health promotion, prevention, and treatment. Addict Behav. 2002;27(6):867-86. https://doi.org/10.1016/S0306-4603(02)00294-0.

37. Skinner HA. Early detection and basic management of alcohol and drug problems. Drug Alcohol Rev. 1985;4(2):243-9. https://doi. org/10.1080/09595238580000411.

38. Betancourt JR, Green AR, Carrillo EJ, Park ER. Cultural competence and health care disparities: key perspectives and trends. Health Aff. 2005;24(2):499-505. https://doi.org/10.1377/hlthaff.24.2.499.

39. Bainbridge R, McCalman J, Clifford A, Tsey K. Cultural competency in the delivery of health services for Indigenous people. Canberra: AlHW; 2015. Cat.no.IHW157. https://www.aihw.gov.au/reports/indigenous -australians/cultural-competency-in-the-delivery-of-health-services-forindigenous-people/formats. Accessed 23 Sept 2019.

40. World Health Organization. World Conference on Social Determinants of Health: Rio Political Declaration on Social Determinants of Health. Rio de Janeiro: WHO. 2011. https://www.who.int/sdhconference/declaratio n/en/. Accessed 24 Sept 2019.

41. The University of Sydney National Centre for Cultural Competence. What is cultural competence? Sydney: NCCC. 2019. https://sydney.edu. au/nccc/about-us/what-is-cultural-competence.html. Accessed 25 Sept 2019.

42. Gone JP. Indigenous traditional knowledge and substance abuse treatment outcomes: the problem of efficacy evaluation. Am J Drug Alcohol Abuse. 2012;38(5):493-7. https://doi.org/10.3109/00952990.2012.69452 8.

43. Ryder C, Mackean T, Coombs J, Williams H, Hunter K, Holland AJA, et al. Indigenous research methodology — weaving a research interface. Int J Soc. 2019;23(3):1-13. https://doi.org/10.1080/13645579.2019.1669923.

44. Prior D. Decolonising research: a shift toward reconciliation. Nurs Inq. 2007;14(2):162-8. https://doi.org/10.1111/j.1440-1800.2007.00361.x.

45. Sherwood J. Do no harm: decolonising Aboriginal health research [PhD thesis]. Sydney: UNSW. 2010.
46. National Health and Medical Research Council. Ethical conduct in research with Aboriginal and Torres Strait Islander Peoples and communities. Canberra: Commonwealth of Australia. 2018. https://www. nhmrc.gov.au/about-us/resources/ethical-conduct-research-aboriginal -and-torres-strait-islander-peoples-and-communities. Accessed 12 May 2020.

47. Lowitja Institute. LIt.Search. Carlton: Lowitja Institute. 2019. https:// www.lowitja.org.au/page/research/lit-search. Accessed 11 Mar 2020.

48. Dale E, Kelly PJ, Lee KSK, Conigrave JH, Ivers R, Clapham K. Systematic review of addiction recovery mutual support groups and Indigenous people of Australia, New Zealand, Canada, the United States of America and Hawaii. Addict Behav. 2019. https://doi.org/10.1016/j.addbe h.2019.106038.

49. Peters D, Tran N, Adam T. Implementation Research in Health: A Practical Guide. Geneva: Alliance for Health Policy and Systems Research, WHO. 2013;27-31. https://www.who.int/alliance-hpsr/resources/imple mentationresearchguide/en/. Accessed on 12 June 2020.

50. Downes MJ, Brennan ML, Williams HC, Dean RS. Development of a critical appraisal tool to assess the quality of cross-sectional studies (AXIS). BMJ Open. 2016;6(12):e011458. https://doi.org/10.1136/bmjop en-2016-011458.

51. Snijder M, Shakeshaft A, Wagemakers A, Stephens A, Calabria B. A systematic review of studies evaluating Australian Indigenous community development projects: the extent of community participation, their methodological quality and their outcomes. BMC Public Health. 2015 https://doi.org/10.1186/s12889-015-2514-7.

52. Pretty JN. Participatory learning for sustainable agriculture. World Dev. 1995;23(8):1247-63. https://doi.org/10.1016/0305-750X(95)00046-F.

53. Wagemakers $A$, Corstjens $R$, Koelen $M$, Vaandrager $L$, van't Riet $H$, Dijkshoorn H. Participatory approaches to promote healthy lifestyles among Turkish and Moroccan women in Amsterdam. Promot Educ. 2008;15(4):17-23. https://doi.org/10.1177/1025382308097694.

54. Allan J. Engaging primary health care workers in drug and alcohol and mental health interventions: challenges for service delivery in rural and remote Australia. Aust J Prim Health. 2010;16(4):311-8.

55. Allan J, Campbell M. Improving access to hard-to-reach services: a soft entry approach to drug and alcohol services for Rural Australian Aboriginal communities. Soc Work Health Care. 2011;50(6):443-65. https:// doi.org/10.1080/00981389.2011.581745.

56. Brett J, Lawrence L, Ivers R, Conigrave K. Outpatient alcohol withdrawal management for Aboriginal and Torres Strait Islander peoples. Aust Fam Physician. 2014:43(8):563-6.

57. Calabria B, Clifford A, Shakeshaft A, Allan J, Bliss D, Doran C. The acceptability to Aboriginal Australians of a family-based intervention to reduce alcohol-related harms. Drug Alcohol Rev. 2013;32(3):328-32. https://doi.org/10.1111/j.1465-3362.2012.00525.x.

58. Calabria B, Clifford A, Rose M, Shakeshaft AP. Tailoring a family-based alcohol intervention for Aboriginal Australians, and the experiences and perceptions of health care providers trained in its delivery. BMC Public Health. 2014;14(1). https://doi.org/10.1186/1471-2458-14-322.

59. Clifford A, Shakeshaft A. Evidence-based alcohol screening and brief intervention in Aboriginal Community Controlled Health Services: experiences of health-care providers. Drug Alcohol Rev. 2011;30(1):5562. https://doi.org/10.1111/j.1465-3362.2010.00192.x.

60. Clifford A, Shakeshaft A, Deans C. How and when health-care practitioners in Aboriginal Community Controlled Health Services deliver alcohol screening and brief intervention, and why they don't: a qualitative study. Drug Alcohol Rev. 2012;31 (1):13-9. https://doi.org/10.111 1/j.1465-3362.2011.00305.x.

61. Clifford A, Shakeshaft A, Deans C. Training and tailored outreach support to improve alcohol screening and brief intervention in Aboriginal Community Controlled Health Services. Drug Alcohol Rev. 2013;32(1):72-9.

62. D'Abbs P, Togni S, Rosewarne C, Boffa J. The Grog Mob: lessons from an evaluation of a multi-disciplinary alcohol intervention for Aboriginal clients. Aust N Z J Public Health. 2013;37(5):450-6. https://doi. org/10.1111/1753-6405.12122.

63. DeVerteuil G, Wilson K. Reconciling Indigenous need with the urban welfare state? Evidence of culturally-appropriate services and spaces for Aboriginals in Winnipeg, Canada. Geoforum. 2010;41(3):498-507. https ://doi.org/10.1016/j.geoforum.2010.01.004. 
64. Gone JP. The red road to wellness: cultural reclamation in a Native First Nations community treatment center. Am J Community Psychol. 2011;47(1-2):187-202. https://doi.org/10.1007/s10464-010-9373-2.

65. Lee KSK, Dawson A, Conigrave K. The role of an Aboriginal women's group in meeting the high needs of clients attending outpatient alcohol and other drug treatment. Drug Alcohol Rev. 2013;32(6):618-26.

66. Legha RK, Novins D. The role of culture in substance abuse treatment programs for American Indian and Alaska Native communities. Psychiatr Serv. 2012;63(7):686-92. https://doi.org/10.1176/appi.ps.201100399.

67. Lovett R, Dance P, Guthrie J, Brown R, Tongs J. Walan Girri: developing a culturally mediated case management model for problematic alcohol use among urban Indigenous people. Aust Health Rev. 2014;38(4):4406. https://doi.org/10.1071/AH13148.

68. Panaretto K, Coutts J, Johnson L, Morgan A, Leon D, Hayman N. Evaluating performance of and organisational capacity to deliver brief interventions in Aboriginal and Torres Strait Islander medical services. Aust N Z J Public Health. 2010;34(1):38-44.

69. Venner KL, Greenfield BL, Hagler KJ, Simmons J, Lupee D, Homer E, et al. Pilot outcome results of culturally adapted evidence-based substance use disorder treatment with a Southwest Tribe. Addict Behav Rep. 2016. https://doi.org/10.1016/j.abrep.2015.11.002.

70. Brady M, Dawe S, Richmond R. Expanding knowledge among Aboriginal service providers on treatment options for excessive alcohol use. Drug Alcohol Rev. 1998;17(1):69-76. https://doi.org/10.1080/09595 239800187611

71. Brady M, Sibthorpe B, Bailie R, Ball S, Sumnerdodd P. The feasibility and acceptability of introducing brief intervention for alcohol misuse in an urban Aboriginal medical service. Drug Alcohol Rev. 2002;21(4):375-80.

72. Kahn MW, Fua C. Counselor training as a treatment for alcoholism: the helper therapy principle in action. Int J Soc Psychiatry. 1992;38(3):208-14.

73. Ferguson FN. A treatment program for Navaho alcoholics: results after four years. Q J Stud Alcohol. 1970;31(4):898-919.

74. Hall RL. Alcohol treatment in American Indian populations: an Indigenous treatment modality compared with traditional approaches. Ann N Y Acad Sci. 1986;472:168-78. https://doi.org/10.1111/j.1749-6632.1986. tb29619.x.

75. Savard RJ. Effects of disulfiram therapy on relationships within the Navaho drinking group. Q J Stud Alcohol. 1968;29(4):909-16.

76. Huriwai T, Sellman DJ, Sullivan P, Potiki TL. Optimal treatment for Maor with alcohol and drug-use-related problems: an investigation of cultural factors in treatment. Subst Use Misuse. 2000;35(3):281-300.

77. Robertson PJ, Futterman-Collier A, Sellman JD, Adamson SJ, Todd FC, Deering DE, et al. Clinician beliefs and practices related to increasing responsivity to the needs of Maori with alcohol and drug problems. Subst Use Misuse. 2001;36(8):1015-32. https://doi.org/10.1081/ JA-100104487.

78. Kalbfleisch PJ. Effective health communication in Native populations in North America. J Lang Soc Psychol. 2009;28(2):158-73. https://doi. org/10.1177/0261927X08330607.

79. Aboriginal and Torres Strait Islander Cultural Capability Team. Aboriginal and Torres Strait Islander patient care guidelines: Communicating effectively with Aboriginal and Torres Strait Islander people. Brisbane: Queensland Health. 2014. https://www.health.qld.gov.au/_data/asset s/pdf_file/0021/151923/communicating.pdf. Accessed 25 Oct 2019.

80. Kelly SB, Robert JM. Disulfiram: an old therapeutic with new applications. Cns Neurol Disord-DR. 2010;9(1):5-12. https://doi. org/10.2174/187152710790966678.

81. Lipworth WL, Wodak AD, Haber PS, Day RO. Why is disulfiram not on the PBS? Med J Aust. 2011;195:7. https://doi.org/10.5694/mja1 1.10708.

82. The University of Auckland. Supply of quantitative research and analysis services: variation in medicines use by ethnicity: a comparison between 2006/7 and 2012/13 Auckland. 2019. https://www.pharmac.govt.nz/ tools-resources/research/maori-uptake-of-medicines/. Accessed Oct 2019

83. Australian Institute of Health and Welfare. Aboriginal and Torres Strait Islander Health Performance Framework (HPF) report 2017. Canberra: AlHW; 2019. Cat.no.IHW194.

84. Oliver SJ. The role of traditional medicine practice in primary health care within Aboriginal Australia: a review of the literature. J Ethnobiol Ethnomed. 2013;9(46):46. https://doi.org/10.1186/1746-4269-9-46.
85. Reeves A, Stewart LS. Exploring the integration of Indigenous healing and western psychotherapy for sexual trauma survivors who use mental health services at Anishnawbe Health Toronto. Can J Counsel Psychother. 2014;49(1):57-78.

86. Allen J, Rasmus SM, Fok CCT, Charles B, Henry D, Qungasvik Team. Multilevel cultural intervention for the prevention of suicide and alcohol use risk with Alaska Native youth: a nonrandomized comparison of treatment intensity. Prev Sci. 2018;19(2):174-85. https://doi.org/10.1007/ s11121-017-0798-9.

87. Allen J, Mohatt GV, Beehler S, Rowe HL. People awakening: collaborative research to develop cultural strategies for prevention in community intervention. Am J Commun Psychol. 2014;54(1-2):100-11. https://doi. org/10.1007/s10464-014-9647-1.

88. Fogarty W, Lovell M, Langenberg J, Heron M-J. Deficit discourse and strengths-based approaches: changing the narrative of Aboriginal and Torres Strait Islander health and wellbeing. Melbourne. 2018;1-29. https ://ncis.anu.edu.au/_lib/doc/ddih/Deficit_Discourse_and_Strengthsbased_Approaches FINAL_WEB.pdf. Accessed on 1 May 2020.

89. Wendt DC, Hartmann WE, Allen J, Burack JA, Charles B, D'Amico EJ, et al. Substance use research with Indigenous communities: exploring and extending foundational principles of community psychology. Am J Community Psychol. 2019;64(1-2):146-58. https://doi.org/10.1002/ ajcp. 12363 .

90. Hall L, Dell CA, Fornssler B, Hopkins C, Mushquash C, Rowan M. Research as cultural renewal: applying two-eyed seeing in a research project about cultural interventions in First Nations addictions treatment. Int Indig Policy J. 2015;6(2):1-15. https://doi.org/10.18584/ iipj.2015.6.2.4.

91. Ober R, Bat M. Paper 1: both-ways: The philosophy. Ngoonjook. 2007;31:64.

92. First Nations Health Authority. First Nations perspective on health and wellness. Vancouver: FNHA. 2019. https://www.fnha.ca/wellness/welln ess-and-the-first-nations-health-authority/first-nations-perspective-onwellness. Accessed 17 Oct 2019.

93. Salmon M, Doery K, Dance P, Williams R, Chapman J, Lovett R. Defining the indefinable: Descriptors of Aboriginal and Torres Strait Islander peoples' cultures and their links to health and wellbeing. Canberra: ANU; 2018. p. 5-31.

94. Best D, Lubman D. The recovery paradigm: a model of hope and change for alcohol and drug addiction. Aust Fam Physician. 2012;41:593-7.

95. Hser Y-I, Anglin DM. Chapter 2 Addiction treatment and recovery careers. In: Kelly J, White W, editors. Addiction recovery management: theory, research and practice. New York: Humana Press; 2011. p. 9-25.

96. Mohatt GV, Rasmus SM, Thomas L, Allen J, Hazel K, Marlatt GA. Risk, resilience, and natural recovery: a model of recovery from alcohol abuse for Alaska Natives. Addiction. 2008;103(2):205-15. https://doi.org/10.111 1/j.1360-0443.2007.02057.x.

97. th United States of America Congress. Indian Health Care Improvement Act (Public Law 94-437: as amended through Public Law 115-91), Washington D.C: Congress; 2017, 113:111-126.

98. Reus VI, Fochtmann LJ, Bukstein O, Eyler AE, Hilty DM, Horvitz-Lennon $M$, et al. The American Psychiatric Association practice guideline for the pharmacological treatment of patients with alcohol use disorder. Am J Psychiatry. 2018;175(1):86-90. https://doi.org/10.1176/appi. ajp.2017.1750101.

99. Best Practice Advocacy Centre New Zealand. Assessment and management of alcohol misuse by primary care. Dunedin: BPAC. 2018;1-10. https://bpac.org.nz/2018/docs/alcohol.pdf. Accessed on 10 May 2020.

100. Spithoff S, Kahan M. Primary care management of alcohol use disorder and at-risk drinking (Part 2: counsel, prescribe, connect). Can Fam Physician. 2015;61(6):515-21.

101. National Ethics Advisory Committee - Kahui Matatika o te Motu. Te Ara Tika guidelines for Maori research ethics: A framework for researchers and ethics committee members. Wellington: HRC. 2010. https://www. hrc.govt.nz/resources/te-ara-tika-guidelines-maori-research-ethics-0. Accessed on 10 May 2020.

102. Government of Canada. Tri-Council Policy Statement: Ethical Conduct for Research Involving Humans TCPS 2 (2018): Chapter 9: Research Involving the First Nations, Inuit and Métis Peoples of Canada. Ottawa: 
Government of Canada. 2018. http://www.pre.ethics.gc.ca/eng/tcps2 -eptc2_2018_chapter9-chapitre9.html. Accessed 12 May 2020.

103. Canuto K, McDermott R, Cargo M. Participant views on participating in a pragmatic randomised controlled trial: the Aboriginal and Torres Strait Islander women's fitness program. Int J Equity Health. 2014;13(1):77. https://doi.org/10.1186/s12939-014-0077-3.

104. Harrison K, Lee KSK, Dobbins T, Wilson S, Ivers R, et al. Supporting Aboriginal Community Controlled Health Services to deliver alcohol care: protocol for a cluster randomised controlled trial. BMJ Open. 2019. https://doi.org/10.1136/bmjopen-2019-030909.

105. Mancall PC, Robertson P, Huriwai T. Maori and Alcohol: a Reconsidered History. Aust N Z J Psychiatry. 2000;34(1):129-34. https://doi.org/10.104 6/j.1440-1614.2000.00693.x.

106. Magwood O, Salvalaggio G, Beder M, Kendall C, Kpade V, Daghmach $W$, et al. The effectiveness of substance use interventions for homeless and vulnerably housed persons: a systematic review of systematic reviews on supervised consumption facilities, managed alcohol programs, and pharmacological agents for opioid use disorder. PLOS ONE. 2020;15(1):e0227298. https://doi.org/10.1371/journal.pone.0227298.

107. Pauly B, Brown M, Evans J, Gray E, Schiff R, Ivsins A, et al. "There is a Place": impacts of managed alcohol programs for people experiencing severe alcohol dependence and homelessness. Harm Reduct J. 2019;16(1):70. https://doi.org/10.1186/s12954-019-0332-4.

\section{Publisher's Note}

Springer Nature remains neutral with regard to jurisdictional claims in published maps and institutional affiliations.
Ready to submit your research? Choose BMC and benefit from:

- fast, convenient online submission

- thorough peer review by experienced researchers in your field

- rapid publication on acceptance

- support for research data, including large and complex data types

- gold Open Access which fosters wider collaboration and increased citations

- maximum visibility for your research: over 100M website views per year

At BMC, research is always in progress.

Learn more biomedcentral.com/submissions 